\title{
A política exterior do Brasil: 1990-2002*
}

\author{
RAÚL BERNAL-MEZA**
}

\section{Introdução}

O Brasil, por seu peso geoeconômico, a dimensão de seu mercado interno e os atributos tradicionais de poder, é o ator de maior importância relativa da América do Sul. Paralelamente a essas condições, sua política exterior teve, historicamente, algumas características diferenciadoras, com uma dose maior de continuidade, juntamente com a formulação e presença de paradigmas que contribuíram para fazê-la mais previsível. Como nós mostramos em um livro recente, a atração por conceitos e categorias ajudou a fazer a política exterior mais compreensível, dando conteúdos mais precisos à formulação da Agenda, à definição de Objetivos e à procura de Instrumentos (Bernal-Meza,2000).

As mudanças sistêmicas certamente causaram mudanças significativas nas políticas exteriores de nossos países e o Brasil, historicamente, não foi a exceção. Isto se refletiu com particular evidência durante as diversas etapas do longo período da ordem bipolar. Aqueles acontecimentos que se sucederam após o fim da guerra fria, que se associaram a um complexo processo de globalização e expansão do capitalismo, despojaram muitos grupos nacionais da decisão de parâmetros-chave ou de “critérios ordenadores” para a formulação da política exterior. Associada a isto, a adoção do que foi chamado o "pensamento único" - ou seja, a aplicação de políticas econômicas neoliberais, baseadas em uma interpretação conservadora das relações entre capital e Estado e entre este e a sociedade civil - teve importantes conseqüências na redefinição das estratégias nacionais de desenvolvimento que, por sua vez, exigiram perfis novos às políticas exteriores. Como assinala Amado Luiz Cervo, comparando o processo sofrido por diversos países da região: "o abandono do paradigma de relações internacionais do Estado desenvolvimentista para favorecer o paradigma neoliberal teve seu impulso inicial, em países de menor porte da América Latina nos meados da década de 1980 e concluiu-se por volta de 1990, com a chegada ao poder dos presidentes Carlos Salinas de Gortari no México,

\footnotetext{
Rev. Bras. Polít. Int. 45 (1): 36-71 [2002]

* Traduzido por Adarene Hallak Pereira da Fonseca.

** Professor Titular de Relações Internacionais da Universidad Nacional del Centro de la Provincia de Buenos Aires e Professor da Universidade de Buenos Aires. Diretor do Centro de Estudos das Relações Internacionais da América Latina, CERIAL, Mendoza, Argentina. Professor Visitante das Universidades de São Paulo-USP e Brasília. Consultor das Nações Unidas, UNESCO e OEA.
} 
Carlos Saúl Menem na Argentina, Carlos Andrés Pérez na Venezuela, Alberto Fujimori no Peru e Fernando Collor de Melo no Brasil. Desse modo, as experiências neoliberiais estender-se-iam sobre o subcontinente como um todo durante a última

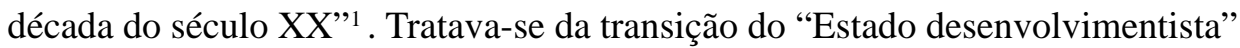
para o "Estado normal" 2 .

Apesar disto, até meados da década de 90, a política exterior brasileira podia ser interpretada "muito mais como uma continuidade daquela desenvolvida no período da política externa independente e consolidada na época do pragmatismo responsável do que como uma nova política, decorrente das alterações mundiais e mesmo das domésticas” 3 .

O fator exógeno para esta continuidade foi o que Lafer chamou de "polaridades indefinidas” (Lafer,1996; Bernal-Meza,2000), que expressavam incógnitas sobre a evolução dos enredos econômicos e políticos onde gravitaram os grandes centros de poder mundial, apesar do desaparecimento da ordem bipolar. Mas isto mudaria a partir da segunda metade da década. O fortalecimento da "nova” hegemonia norte-americana e a implementação, pela aliança vencedora da Guerra Fria, da "Agenda de valores hegemônicos universalmente aceita” (Vigevani et. al., 1999; Bernal-Meza,2000) abriram novos contextos de vulnerabilidade para o Brasil, que se caracterizariam pela adoção dos padrões internacionais de normas de proteção do trabalho, dos direitos humanos, do meio-ambiente, dos inventos, dos consumidores, entre outros. Estes foram somados a condicionamentos tradicionais, como os referentes à segurança e à exploração da Amazônia. O mais importante então foi que o presidente Fernando Henrique Cardoso procurou se aproximar dos Estados Unidos e - depois de ter impelido iniciativas em contrário terminaria por ir pragmaticamente à ALCA.

Segundo Roett ${ }^{4}$, a política exterior brasileira foi confrontada a uma série de novos e cambiantes temas de política internacional: a imprevisível dinâmica da globalização, a participação ativa nas iniciativas multilaterais e os desafios e oportunidades da integração regional e da cooperação na segurança; três assuntos que deveriam ser de alta prioridade para a Administração que assumirá após a corrida presidencial de 2002.

O estudo que se segue procura identificar estes processos de mudança na política exterior do Brasil, com o propósito de dar uma visão geral do que foi sua evolução no período em questão. Para isto, depois de uma introdução e de dar uma visão geral da política exterior no período 1980-2000, é feita uma interpretação teórico-analítica dos paradigmas, conceitos e categorias que permitiram fazê-la mais compreensível pela análise do observador. Posteriormente, ingressa-se no estudo do período específico, tomando como eixo de preocupação o Mercosul e a construção de parcerias estratégicas, entre elas com a Argentina.

A análise de sua "diplomacia econômica" nos permite, subseqüentemente, avaliar a aproximação do Brasil à ALCA, enquanto que a análise sobre as 
percepções da "segurança" facilita abordar a questão do poder e sua relação com a política interna e externa. Finalmente, são analisados a Agenda, os Objetivos e o Estilo que caracterizaram a política exterior no período, e são apresentadas as conclusões.

\section{A trajetória da política exterior: dos anos 1980 até 2000}

Depois de um período de marcado dinamismo em política exterior, caracterizado pelo “pragmatismo ecumênico responsável” (abertura para a África; participação ativa nas agendas do mundo em desenvolvimento etc.) que acompanhou a grande expansão do modelo de industrialização e exportação de manufaturados dos anos 70, com um forte crescimento econômico, mudanças internas e externas levaram a uma sensação de estagnação e decadência destas estratégias. O Brasil começou a viver uma fase crítica, onde ambas as estratégias comprovaram seu esgotamento. Com efeito, o modelo de política exterior da década de 1980, das presidências Figueiredo e Sarney, associado ao "desenvolvimento nacional” deu lugar a uma fase de crise e contradições (Cervo \& Bueno,1992; Cervo;1994). Como assinalou outro autor, durante os anos 70 e 80 , a diplomacia brasileira teve pequena margem de iniciativa na maioria das questões internacionalmente relevantes e foi condenada a reagir a investidas do exterior, as quais não podia prever nem controlar, fazendo com que no período a política exterior fosse basicamente reativa e defensiva (Guilhon Albuquerque, 2000; 2001). Apesar disso, do nosso ponto de vista, o governo Sarney seria o último do século a identificar a política exterior com o "terceiromundismo".

Da transição democrática da década seguinte para a expansão, símbolo dos novos tempos, surgiria - como exemplo de grande renovação - uma mudança fundamental nas relações bilaterais com a Argentina e, em geral, com a América do Sul: O Brasil encontrou seu perfil latino americano, substituindo as políticas e percepções de conflito e rivalidade pelas de cooperação e acordo (Bernal-Meza, 1989; 2000).

Nesse contexto, a candidatura de Collor de Melo (1989) lança sua plataforma de política exterior, gerando três tipos de expectativas (Hirst \& Pinheiro;1995): atualizar a agenda internacional do país; construir uma nova agenda prioritária e não conflitiva com os Estados Unidos e reduzir o perfil "terceiromundista”, haja vista as mudanças acontecidas no cenário político internacional. Cada uma destas expectativas implicou um tema prioritário, que foi refletido em iniciativas específicas: recuperação do protagonismo e organização da ECO 92; negociação e assinatura do tratado do Mercosul e iniciativas em relação à segurança, definindo posições mais flexíveis nos tratados de não-proliferação (assinatura do acordo de criação da Agência Brasileiro-Argentina de Contabilidade e Controle de Materiais Nucleares e do Acordo Nuclear Quatripartite de Salvaguardas com a AIEA; proposta de revisão do Tratado de Tlatelolco, etc.). 
Na parte econômica, o governo de Collor se aproxima das tendências predominantes no Chile, México e Argentina, de políticas neoliberais. Não obstante, suas medidas só alcançariam parcialmente a anulação de tarifas, a abertura a novos segmentos de importação e a eliminação de alguns subsídios e incentivos fiscais para a produção ${ }^{5}$.

As expectativas lançadas pela política exterior de Collor mudaram completamente como conseqüência da crise política interna que levaria à destituição do presidente e à sua substituição pelo vice-presidente, Itamar Franco. Não obstante, é necessário mostrar que aquelas já tinham sido debilitadas pelas próprias contradições da política, como impulsionar o terceiromundismo e, ao mesmo tempo, dar concessões no tratamento da dívida externa. Franco retomou alguns temas da agenda Collor e levou adiante o cumprimento de compromissos internacionais (não proliferação): o Brasil ratificou o Tratado de Tlatelolco e se aprofundaram as medidas de confiança recíproca com a Argentina. Procurou-se manter um baixo perfil com os Estados Unidos, afim de se evitar o aprofundamento das diferenças. Junto a isto foi somada uma nova dimensão na política exterior: a idéia do Brasil como país continental e global trader, política que aproximou Brasília a outras "potências médias”, como China, Índia e, depois, Rússia.

Os âmbitos de ação primordiais seriam dois; cada um refletido na proposta de novos objetivos políticos. O primeiro foram as Nações Unidas, cenário ao qual o Brasil se aproximou ante seu novo (assumido) papel de "potência média", propondo sua própria candidatura a membro permanente do Conselho de Segurança da ONU; o segundo foi a América do Sul, onde teria duas linhas de ação: a proposta de criação da ALCSA (Acordo de Livre Comércio da América do Sul) e o relançamento da cooperação econômica e de integração em infra-estrutura com a Venezuela, Colômbia, Uruguai e Bolívia.

A proposta de criação da ALCSA (realizada em Santiago do Chile em 1994 pelo próprio Franco) - na prática, uma extensão do Mercosul - teria necessária e imediatamente uma interpretação em relação aos Estados Unidos: foi uma proposta alternativa à criação da ALCA. Porém, ela também refletiu a sensação de que as relações com os Estados Unidos se aprofundavam negativamente, em torno de temas-chave da agenda bilateral: propriedade intelectual, meio ambiente, direitos humanos, papel dos militares na condução política da agenda de segurança etc. Esse é o cenário de propostas, iniciativas e percepções que encontra Cardoso em sua chegada ao governo, embora ele havia conduzido - na qualidade de chanceler - a política exterior de Itamar Franco e, portanto, a transição da mesma do "terceiromundismo" para o "pró-ocidentalismo" e, em particular, para uma aproximação política com os Estados Unidos.

Cardoso aprofunda as relações com o Mercosul e, em particular, com a Argentina. Mas em ambos os objetivos-cenários (Estados Unidos e Argentina), problemas surgiriam. Em primeiro lugar, ficou cada vez mais difícil para o Brasil 
desenvolver um calendário positivo com os Estados Unidos. Os temas ALCANAFTA-ALCSA - que sintetizam a presença dominante do paradigma de política exterior de competição com os Estados Unidos e a continuidade do objetivo do desenvolvimento industrial nacional e autônomo - e os obstáculos norte-americanos para as exportações brasileiras (como elemento conjuntural), se constituem nos eixos centrais da discórdia. Em segundo lugar, as diferenças com a Argentina se centraram nas políticas de segurança, nas interpretações sobre a ordem mundial e nas respectivas relações com os Estados Unidos (Bernal-Meza, 1999; 2000; 2000a; 2000b).

Até o presente nota-se que a dimensão comercial tem sido a mais explorada nos modos de inserção internacional do Brasil, o que faz com que o debate sobre essa inserção se concentre no aspecto comercial, enquanto que o político se mantém em baixa. Não obstante, o único modo de aspirar a um reconhecimento como potência regional e como potência média mundial, a partir de sua condição de paíscontinente, fará necessariamente com que o país tenha que assumir posições a respeito de diversos tópicos da agenda mundial, o que levará a um aumento significativo do perfil político da inserção internacional. Este é um ponto particularmente relevante em relação ao destino do Mercosul, na medida que a decisão sobre a política global deverá passar por uma definição de interesses (e objetivos) de longo prazo sobre o bloco subregional, e por uma revisão das relações com a Argentina.

\section{Uma interpretação teórico-analítica da política exterior}

No discurso e na formulação da política exterior do Brasil, historicamente, nota-se a apelação a conceitos e categorias que contribuíram para fazer mais explicativa e mais compreensiva a política exterior seguida pelo país e a presença nesta dos temas de sua agenda, dos objetivos buscados e dos instrumentos usados para alcançá-los.

Entre esses conceitos e categorias estão os de "universalidade”, “multilateralismo" e "parcerias estratégicas”. Porém, os mesmos não permaneceram estáveis nem imutáveis através do tempo; pelo contrário, eles sofreram ajustes e reformulações. Deste modo, embora a política exterior brasileira se caracterize pelo multilateralismo e pelo universalismo, este último - embora seletivo - será a característica da inserção internacional durante os anos 90 .

A eleição de "parcerias estratégicas”, contanto que com sócios preferenciais, foi resultado da nova formulação e implementação da política exterior, cuja síntese era o universalismo seletivo, no qual se percebe a necessidade de levar adiante aproximações específicas (eleitas como opção) que permitem alcançar objetivos comuns com potências regionais semelhantes, tirar proveito de oportunidades e enfrentar desafios. 
A partir de 1985 o Brasil constrói sua parceria estratégica com a Argentina - considerada a principal e mais ampla, que serviria de plataforma para redefinir as relações no plano regional - dentro do seu universalismo seletivo. Permitiu proporcionar instrumentalidade ao universalismo dos anos 80 e renová-lo à luz dos novos cenários, ao mesmo tempo em que mantinha sua vocação mundial.

Esta vocação retornou com força no início do século XXI. A elevação da parceria com a Rússia ao nível de "associação estratégica de longo prazo"6 incorpora os elementos de alta política, militar-estratégicos e políticos, necessários para a reformulação da posição do Brasil no sistema mundial.

Em relação aos países em desenvolvimento, as parcerias estratégicas, desde meados dos anos 80, se concentraram na China, Índia e, depois, na Argentina e África do Sul. Tanto no caso da China como no da Índia, esta tendência, manifestada em meados da década de 80, tinha surgido como conseqüência da identificação de posições comuns no seio da ONU. Porém, o conflito indo-paquistanês reativado nos últimos anos da década de 90 e a política de proliferação nuclear da Índia fizeram surgir uma diferença com o Brasil que marcou a alienação mútua, na medida em que este país abandonava a opção militar-estratégica do desenvolvimento nuclear.

A construção de parcerias durante os anos 90 se deu de acordo com a visão de liberalismo econômico que prevaleceu na condução da política exterior. A exceção a esta regra foi a política africana e a criação da Comunidade de Países de Língua portuguêsa ${ }^{7}$, que Saraiva definiu como "o espaço privilegiado para a reafirmação da África como um dos objetivos insubstituíveis da política exterior brasileira” (Saraiva,2001:46).

Porém, nestas construções estratégicas é possível que tenham surgido ou que possam se apresentar no futuro algumas contradições, derivadas de objetivos divergentes nas agendas dos atores. Por exemplo, o objetivo global de aliança com a China pode ser incompatível com a meta regional de um continente de paz e prosperidade (Guilhon Albuquerque, 2000). A avaliação supõe o desenvolvimento eventual de uma agenda de segurança, militar-estratégica, por parte da China, conforme a sua condição de "potência nuclear", que poderia discordar com aquelas agendas impelidas pelo Brasil; possivelmente também com as de um Mercosul político, estas últimas alinhadas com a agenda hoje predominante no Brasil e na Argentina, de valores hegemônicos universalmente aceitos (Bernal-Meza, 2000).

Deste modo, a reformulação ou atualização dos marcos conceituais da política exterior brasileira, em termos de mudanças da visão orgânica do mundo e da localização do Brasil, foi menos evidente que a vivida por outros países da região, como a Argentina e o Chile. Do ponto de vista da existência de articulações conceituais específicas, no eixo ou continuum “autonomia-desenvolvimento”, houve um maior continuum de idéias desenvolvimentistas e autonomistas. Em termos de continuum “continuidade-ruptura” nas orientações da política exterior, a brasileira 
manteve uma maior permanência na tradição de sensibilidade aos conceitos e visões desenvolvimentistas e ao paradigma norte-sul. Assim também, a vinculação entre reformas econômicas e mudanças conceituais (idéias) na política exterior foi menor. A hipótese foi mais pela preservação de espaços de autonomia, ou seja, a necessidade de negociar os termos de ingresso nos regimes internacionais, entendendo que essa autonomia maximizou, a longo prazo, as possibilidades de obter benefícios para o desenvolvimento e o posicionamento internacional.

Como em outros países da região, a atração pelos interesses nacionais para justificar a política (interna e externa) do poder foi uma constante no Brasil. A política exterior foi, até o presente, desenhada a partir da atração a este tradicional conceito realista do interesse nacional. Nas referências a diversos autores que nós fazemos nestas páginas isso se torna evidente. Mas, se for levado em conta que o interesse nacional é um conceito ambivalente, tautológico, que representa tanto instrumentos como objetivos, é conveniente lembrar que esta é, definitivamente, a expressão daquilo que os tomadores de decisão, em nome do Estado, identificam. Em uma sociedade que ainda mantém traços essencialmente pouco democráticos - em termos sociais, de distribuição da riqueza, de participação e acesso à educação e outros mecanismos de ascensão social por parte dos grupos étnicos subordinados (como negros, mulatos e índios) - a apelação ao conceito realista traz o risco de os conteúdos da política agirem em benefício daqueles setores que têm acesso ou que podem participar dos processos de formulação e tomada de decisões, sendo grupos de pressão ou partes das estruturas burocráticas do processo decisório. Essa situação, explicável no caso brasileiro, é também - com variações - aplicável a vários outros países da região. Dentro do Mercosul, os casos do Chile e da Argentina ainda mantêm características de apelação ao termo para a fundamentação de suas políticas.

Embora Cardoso não faça diferente, de acordo com Soares de Lima, seu governo é o que mais diferencia (desde o fim do ciclo militar) o componente governamental do componente estadista da política exterior. "Este último, representado pelo conceito de interesse nacional, se defende na idéia nãodemocrática de que, por causa do interesse nacional, a política exterior está acima da política e dos partidos” ${ }^{\text {. }}$

\section{A formulação das novas relações com a Argentina}

As novas relações com a Argentina, que passaram do conflito à cooperação e que se sintetizaram na construção de uma aliança estratégica, podem ser consideradas como o melhor exemplo na revisão da estratégia internacional do Brasil. Elas se inscreveram no desenvolvimento de parcerias estratégicas, dentro do universalismo seletivo que caracterizaria a política exterior brasileira em meados dos anos 80 . 
A partir de 1985 o Brasil constrói sua parceria estratégica com a Argentina, considerada a principal e mais ampla, que serviria de plataforma para redefinir as relações no plano regional. Como mostram alguns autores brasileiros, "do ponto de vista do Brasil, a parceria estratégica com a Argentina nada tem a ver com um entrincheiramento no Cone Sul. Na verdade, é o contrário: a parceria, ao dissolver a tradicional rivalidade platina, funciona como plataforma para a superação do modelo das duas bacias. Pela primeira vez na história, o Brasil torna-se capaz de olhar para a América do Sul sem a distorções criadas pelos óculos bifrontes do passado. Assim, abre-se um horizonte novo, que é o da integração sul-americana” (Magnoli, César \& Yang, 2000:48).

\section{O Mercosul na política exterior do Brasil: projeto político e geoeconomia}

Existem diversos elementos de análise - entre eles a própria realidade que apóiam a tese segundo a qual o processo de crescimento do Brasil gerou uma distribuição desigual da riqueza. Os seguintes estrangulamentos internos (crise do modelo Industrialização Substitutiva de Importações) e externos (impacto das diversas crises internacionais, da subida do petróleo dos anos 70 às diversas crises econômico-financeiras desta década e da seguinte), derivaram da idéia de que era necessário desenvolver um novo projeto nacional, um de cujos pontos centrais seria a inserção competitiva na economia internacional, ampliando o comércio exterior e melhorando a competitividade da indústria, através do fortalecimento tecnológico, do aumento da qualidade dos recursos humanos e da infra-estrutura de qualidade.

A associação com a Argentina, primeiramente, e a iniciativa do Mercosul, foram concebidas como instrumentos importantes, mas não bastantes para a redefinição dessa nova inserção internacional. O desafio era passar de uma economia fechada a uma economia competitiva internacionalmente. A conformação de uma ampla área geoeconômica no Cone Sul serviria como plataforma de negociação frente aos megablocos.

A preocupação do Brasil em iniciar a aproximação com seus vizinhos foi motivada, primeiramente, por um interesse político; mas uma vez dada esta convergência, ela também adquiriu uma motivação econômica, ainda que os incentivos econômicos associados ao projeto Mercosul sempre fossem vistos como limitados; segundo autor, principalmente em função da assimetria de tamanho entre este país e seus sócios (Veiga, 2001). Não obstante, no contexto das profundas mudanças externas e seus impactos internos, a integração subregional - e particularmente a associação com a Argentina - adquiriu uma importância especial, já que a construção do projeto Mercosul foi percebida como um instrumento que permitiria enfrentar a nova situação do sistema internacional, com melhor capacidade política e econômica. 
O Mercosul foi, deste modo, uma alternativa intermediária entre a continuidade de sua política nacionalista e a economia liberal predominante no mercado mundial. Dentro do bloco, o Brasil exercia pressões protecionistas que seriam impossíveis de se levar adiante no contexto de um acordo como a ALCA. Isso também faria do Mercosul uma instância negociadora frente ao eventual estabelecimento de uma área hemisférica de livre comércio e, a nível político, o bloco permitiria dotar o Brasil de uma base maior de apoio para sua estratégia de alcançar reconhecimento como "potência média mundial”, em virtude da liderança que exerceria no interior do bloco e, através deste, no Cone Sul. O Brasil intentava assim disputar com os Estados Unidos a hegemonia em âmbito subregional sulamericano.

O enfoque brasileiro se construiu de uma visão de realpolitik. Um dos exemplos é o fato de que "nas negociações com os sócios brasileiros no MERCOSUL, a afirmação de promessas de desenvolvimento industrial nacional se expressa sistematicamente como um processo de competição econômica com os sócios e quase nunca como cooperação" (Veiga,2001).

Duas conclusões podem ser tiradas como conseqüência da presença dessa visão. A primeira, que o Mercosul aparece para o Brasil como um cenário internacional mais próximo, do ponto de vista dos interesses comuns; a segunda, que ante eventuais problemas internos que afetaram sua coesão nacional, o país priorizava a resolução dos mesmos sobre a vinculação com seus sócios. Como veremos mais adiante, esta foi a lógica determinada. Portanto, a política exterior que o Brasil teria com o Mercosul seria aquela que lhe permitiria responder aos novos desafios internacionais. A vantagem do Brasil não implicava vantagem para o resto dos sócios do Mercosul (pela disponibilidade de um enorme mercado interno). O Itamaraty sempre teve isso claro e usou essa situação em seus trabalhos, conseqüentemente.

Em suma, a política brasileira para o Mercosul teve três finalidades: 1) permitir abrir gradualmente sua economia à economia mundial, fortalecido pela amplificação do mercado subregional, e logo regional (ALCSA), graças aos ganhos de escala; 2) enfrentar os desafios econômicos e políticos das estratégias hegemônicas norte-americanas na América Latina (ALCA); 3) alcançar o reconhecimento mundial como potência média, graças à sua liderança política no bloco e à dimensão de um mercado que o teria como o centro econômico-industrial fundamental.

\subsection{A política exterior do período Mercosul:}

Uma síntese da agenda da política exterior brasileira do período CollorFranco mostraria a intensificação das medidas de confiança recíproca com a Argentina, em matéria de segurança, como um importante progresso. Outros 
elementos que caracterizariam a agenda foram: a busca de pouco relacionamento com os Estados Unidos, ou seja, uma agenda não conflitiva; o fortalecimento do multilateralismo; a incorporação da idéia de Brasil global trader e, ao mesmo tempo, a intensificação do retorno à América Latina (Mercosul-ALCSA). FHC mantém as linhas políticas de Itamar Franco. Intensifica a procura de reconhecimento internacional do Brasil como "potência média”, mas, ao mesmo tempo que declara a aspiração à liderança política no âmbito sul-americano ${ }^{9}$, continua explorando a dimensão comercial como a forma predominante de inserção internacional ${ }^{10}$.

O alicerce da política exterior com o Mercosul deveria ser a relação com a Argentina, mas, logo após a destituição do presidente Collor, começaram a evidenciar-se as diferenças nas políticas exteriores de ambos os países, que se centraram em cinco grandes núcleos: 1 - as interpretações sobre a "ordem mundial emergente ou em transição" e a sobre a "globalização"; 2 - o papel que cada um destes países aspirava nesses contextos; 3 - os paradigmas dominantes em política exterior; 4 - as relações com os Estados Unidos; 5 - as políticas de segurança ${ }^{11}$.

Um fator particularmente irritante para a Argentina foi o retorno da aspiração brasileira a entrar como sócio permanente no Conselho de Segurança da ONU, proposta que relançou Cardoso e que desatou uma verdadeira controvérsia com seu vizinho. A Argentina rejeitou esta iniciativa recorrendo a fundamentos realistas ${ }^{12}$, e o governo brasileiro, com o propósito de evitar confrontações estéreis - posto que sem o consentimento argentino esta candidatura parecia inviável -, arquivou o tema até o início da década seguinte.

Deste modo, na recente visita de Cardoso à Rússia (14 de janeiro de 2002) o tema da candidatura ao Conselho de Segurança apareceu como um dos temas políticos chave da agenda do encontro presidencial russo-brasileiro. Putin apoiou a eventual admissão do Brasil como membro permanente do mesmo ${ }^{13}$, o que deveria gerar novas dificuldades com Buenos Aires no futuro.

\subsection{As perspectivas do MERCOSUL e a política exterior:}

Para o Brasil - em tese - o Mercosul tinha sido (pelo menos até a crise de 1999) um instrumento estratégico de sua política global, fundado nos objetivos antes assinalados. O Mercosul era, efetivamente, um instrumento de realpolitik.

Porém, na realidade, haveria profundas contradições entre teoria e prática. Enquanto a percepção sobre o Mercosul mudava - diminuindo seu perfil de importância estratégica, como conseqüência dos significativos retrocessos nas ambições ou interesses mais globais, produto de uma situação ou percepção da própria fraqueza econômica e financeira -, endurecia-se a posição frente à Argentina e o objetivo em relação a esta pareceu ser mais a vontade de pôr seu sócio de joelhos, por meio de pressões e um relativo grau de intransigência, fazendo 
pagar, comercialmente, o desprezo à política exterior. Porém, poderia essa ser considerada uma política de Estado racional?

\subsection{O Mercosul em crise (1999)}

Os problemas de política exterior entre os dois principais sócios se arrastaram desde princípios dos anos pós Collor enquanto, paradoxalmente, a interdependência comercial e econômica aumentava e, durante os primeiros anos da década de 1990, cresciam as coincidências em torno do neoliberalismo como modelo de política interna. Estes fatos não puderam ser considerados como o eixo ou o núcleo endógeno responsável pela debilidade do Mercosul como instrumento estratégico da inserção internacional destes dois países e dos sócios restantes, nem tampouco a sucessão de medidas e contramedidas comerciais unilaterais com que cada país respondeu ao outro. O problema central se situou na indefinição do Brasil em levar adiante o que a sua própria decisão política definiu em seu momento como "o mais importante projeto de política exterior" ${ }^{14}$.

Autores diversos, entre eles este ${ }^{15}$, têm tratado da razão pela qual o Mercosul não passou de um projeto essencialmente comercial. Muito da responsabilidade cabe ao Brasil, que até o fim do governo de De la Rua, reivindicou à Argentina - ou a questionou - dois tópicos que impediam progressos econômicos e políticos: o fim da Conversibilidade, considerada como o mais importante fator desestabilizador para a expansão da integração econômica; a relação preferível de Buenos Aires por Washington.

Se a atual situação que vive a Argentina, depois da fase transitória de quatro presidentes em poucas semanas, agora sem a Conversibilidade da moeda e com uma relação provavelmente menos estreita com os Estados Unidos, não conduz a um melhoramento das perspectivas políticas para relançar o Mercosul, é porque - tal como informamos (Bernal-Meza, 1999a; 2000; 2001), o progresso do projeto passa pelo sucesso dos programas nacionais de crescimento e desenvolvimento (sabendo que a integração é justamente um instrumento com essa finalidade), por um compromisso de avançar na institucionalidade e nos progressos nos acordos de compatibilização e harmonização macroeconômica. Mas o Brasil está preparado e disposto para este desafio?

Para dar essa resposta, o país precisa resolver a equação inconclusa: combinar positivamente um projeto de alta motivação política e restritos incentivos econômicos. O Mercosul continua sendo um dilema para a agenda brasileira ${ }^{16}$.

\section{A diplomacia econômica do Brasil}

Ao longo da década de 90, o Brasil estava abandonando sua tradição de negociações externas setoriais limitadas, cuja maior expressão foi no âmbito da 
ALALC e ALADI, para passar - dentro de um processo de liberalização comercial preferencial - para uma participação mais destacada em âmbito multilateral.

Historicamente o Brasil esteve presente nas negociações do GATT e da OMC aspirando a participar das garantias de liberalização do comércio com o menor custo possível. Durante a Rodada Uruguai, para o governo brasileiro, "as vantagens de evitar concessões na esfera do novos temas pareciam superar em muito os benefícios relacionados à liberalização nas questões tradicionais” (Abreu, 2001).

Até o governo Sarney, a percepção era de um relativo temor frente à abertura e à incorporação dos "novos temas" da agenda (Rodada) Uruguai. A presunção (realista) era de que o país teria pouca capacidade competitiva industrial e tecnológica, o que faria com que essa participação ocorresse de uma perspectiva desfavorável. A posição “terceiromundista” se justificava porque, compartilhando o discurso do mundo em desenvolvimento, se participava de um esforço que buscava mudar os comportamentos prejudiciais dos países desenvolvidos; o país não teria capacidades para ditar regras internacionais. Os maiores temores se situavam justamente nas negociações do GATT. ${ }^{17}$

Não obstante, as mudanças acontecidas na economia e na política mundiais em fins dos anos 80 e o aumento da importância dos temas econômicos na agenda internacional fizeram aumentar a participação e o interesse do Brasil neste organismo. Ao mesmo tempo, o compromisso e interesse com as atividades da UNCTAD se intensificaram, culminando na eleição do embaixador Rúbens Ricúpero como Secretário Geral.

Desde o início dos anos 90 a abertura e a flexibilidade frente às demandas das grandes potências capitalistas - em particular as provenientes dos Estados Unidos - começaram a identificar a mudança de posição frente ao multilateralismo. O Brasil se dissocia da posição do grupo de países em desenvolvimento, em particular quanto ao questionamento global da ordem econômica internacional, ainda quando se criticam algumas políticas dos países industrializados (protecionismo comercial e restrição à difusão de tecnologias de ponta). "Demonstrações de boa vontade na relação com os Estados Unidos estavam sendo feitas no início dos anos 90, quando a lei de patentes já tramitava no Senado Federal desde 1993, havendo, ainda, dois projetos de lei sobre direitos autorais, enquanto a nova lei brasileira de propriedade industrial (n824/91) tinha sido aprovada pela Câmara dos Deputados em junho do mesmo ano" (Miyamoto, 2000:128).

Segundo Guilhon Albuquerque, do ponto de vista comercial, a atitude do país se tornou mais positiva e propositiva. O GATT e, por extensão, a OMC, deixaram de ser avaliados como instrumentos de abertura forçada de mercados em benefício dos países industrializados, passando a ser vistos como instrumentos de convergência entre os interesses distintos de países exportadores e importadores das mais diversas dimensões e capacidades econômicas (Guilhon Albuquerque, 
2000). O Brasil aceitou as limitações que a Rodada Uruguai impôs, e participou ativamente da OMC em troca da garantia que um sistema judicial de solução de controvérsias seria implementado. Os mecanismos de solução de controvérsias e a agricultura foram as prioridades da diplomacia econômica brasileira nas negociações da $\mathrm{OMC}^{18}$. Não obstante, também parece possível que a posição mais flexível do Brasil frente às exigências de maior liberalização provenientes das economias mais desenvolvidas foi coincidente com a volta a políticas neoliberais que caracterizariam a agenda governamental dos anos 90. Desde o fim da década anterior o país havia embarcado na liberalização unilateral (Abreu, 2001). Foi dali, desde Montreal, que o Brasil começou a convergir com a tendência dominante, especialmente no que se referia aos "novos temas" (TRIPS) e com a posição norte-americana na liberalização agrícola.

Fiel à sua opção predominante pela dimensão comercial da política exterior (Bernal-Meza, 2000), o Brasil continuou promovendo iniciativas neste campo e assumiu uma posição intermediária. Nesse sentido, o Itamaraty apresentou à OMC, no fim de dezembro de 2001, uma proposta para aumentar o número de funcionários de economias periféricas na organização ${ }^{19}$. A proposta procurou aumentar a participação do Brasil nos foros econômicos internacionais. Contudo, esse maior ativismo e compromisso internacional do Brasil, expressado no seu multilateralismo econômico, não trouxe ainda os resultados esperados e este aspecto se constituiu em um dos pontos chave sobre os quais se sustentaria a crítica à política exterior de Cardoso.

\subsection{A recuperação da parceria estratégico com a Rússia:}

No que parece ser a última visita oficial de Cardoso a Moscou, o encontro com Putin, realizado ao terminar a primeira quinzena de janeiro de 2002, serviu como relançamento da parceria estratégica com a Rússia, que havia sido praticamente deixada de lado desde sua primeira formulação, em benefício de relações mais positivas com os Estados Unidos. Na oportunidade, a agenda se estabeleceu sobre questões econômico-comerciais, de segurança (que abordamos separadamente) e de política internacional.

Na primeira das agendas, o acordo buscou duplicar o volume de intercâmbio comercial bilateral, que foi de 1,567 bilhões de dólares no ano de 2001. Por sua vez, a agenda de política internacional significou apoio mútuo para as iniciativas, que para cada país parecem hoje relevantes no contexto da nova ordem mundial e da economia global. Deste modo, enquanto o Brasil obteve apoio para o relançamento de sua candidatura como membro permanente do Conselho de Segurança da ONU, a Rússia recebeu o respaldo brasileiro para sua entrada na OMC.

As coincidências em matéria de política internacional alcançaram os temas mais conflitantes desta agenda: o terrorismo, a situação do Oriente Médio, a crise 
argentina e a decisão do presidente Bush de abandonar o Tratado ABM de mísseis antibalísticos. Cardoso apoiou a posição de Putin, que qualificou como "erro" a decisão do governo norte-americano, havendo ainda visões coincidentes sobre os temas restantes.

\section{A política exterior do Brasil e sua aproximação da ALCA}

Foi durante a administração do chanceler de Cardoso, Felipe Lampreia, que a política exterior brasileira começou a mudar sua posição vis-à-vis a ALCA, passando da rejeição - ou, pelo menos a extensão do início - das negociações, para um ponto de convergência positivo com os Estados Unidos, ainda quando o discurso da política tenha continuado impregnado das tradicionais posições desenvolvimentistas e autônomas ${ }^{20}$.

Quem mudaria o discurso, fazendo-o coincidente com a prática, seria Celso Lafer. Os fundamentos da mudança obedeceram a um conjunto de fatores que deterioraram as expectativas postas em outros cenários de negociação: o fracasso das negociações entre a União Européia e a América Latina e o impasse no tema agrícola; as dificuldades encontradas na OMC para limitar o protecionismo dos países desenvolvidos, o fracasso da reunião de Seattle e o estado de estagnação do Mercosul, onde a crise argentina tornara inviável o seu "relançamento"(Guilhon Albuquerque, 2001). Assim, ante o risco de um eventual isolamento da sua posição, e na perspectiva que outros países sul-americanos declarassem seus interesses em chegar a um acordo bilateral com os Estados Unidos e avançar na agenda de negociações, que incluía países membros e associados do Mercosul (Argentina, Uruguai e Chile), o Brasil mudou sua posição, iniciando um caminho cujo objetivo era agora transformar-se no principal interlocutor dos Estados Unidos nas negociações com a América Latina ${ }^{21}$. Os dois convites para entrevistas que 0 atual presidente Bush fez ao seu homólogo brasileiro mostram a relevância deste assunto. O Brasil concordou em participar da ALCA e mudou o discurso de sua política exterior: A ALCA é uma oportunidade ${ }^{22}$.

Mas outros três elementos também contribuíram para a manutenção desta posição: em primeiro lugar, a própria adscrição do governo brasileiro ao modelo neoliberal (Bernal-Meza, 1999; 2000; Cervo, 1999, 2000; Guilhon Albuquerque, 2000; 2001). Em segundo lugar, a mudança que vinha se registrando no comércio exterior. Com efeito, em 2001 os Estados Unidos passaram a ser o principal destino das exportações brasileiras (em particular de manufaturados), com mais que 30\% do total, deixando o Mercosul em segundo lugar como destino das mesmas. Por último, a extrema fragilidade da economia brasileira, logo após as crises da Tailândia (1997) e da Rússia (1998), quando os riscos de uma corrida contra o Real levaram Cardoso a fechar um acordo com os organismos multilaterais de crédito e com o governo norte-americano, para apoiarem a moeda em troca de um pacote de 
reformas fiscais, comerciais e financeiras que levariam, entre outros aspectos, à flutuação do Real (janeiro de 1999). Neste sentido, a aproximação com os Estados Unidos e as medidas econômicas implementadas, que incluíam a privatização de setores estratégicos, contribuíram (supostamente, na ótica do governo) para recuperar a confiança dos investidores internacionais.

Não obstante, o chanceler Celso Lafer, durante o ano de 2001, reafirmou em diversas oportunidades a prioridade do Mercosul como opção estratégica principal do Brasil. Mas, frente à dúvida "a ALCA vai conviver bem com o Mercosul?”, o embaixador Rúbens Ricúpero, em entrevista publicada pela RelNet, afirmou em meados do mesmo ano que era difícil indicar a priori se a ALCA inviabilizaria o Mercosul e que isso dependeria de como se negociaria o projeto hemisférico.

Apesar da aproximação com os Estados Unidos, que impeliu a presidência de F.H. Cardoso durante os anos 90, o Brasil manteve as estratégias regionalistas que foram definidas no começo da década, ${ }^{23} \mathrm{em}$ um contexto de pós-guerra fria, de hegemonia ideológica do neoliberalismo e sob o paradigma do regionalismo aberto, tal como o Mercosul. Mas não havia nenhuma contradição - apesar de que uma leitura a grosso modo mostrou que o Brasil resistiu durante grande parte da década às iniciativas norte-americanas (ALCA) - porque o padrão Mercosul era funcional às políticas econômicas neoliberais que aplicaram os governos de Menem, Collor, Cardoso e De la Rúa, graças a sua adscrição ao paradigma do regionalismo aberto. O contrário é imaginar que a integração do Cone Sul tinha evoluído para um modelo de regionalização antes que para a globalização (Bernal-Meza, 1999b; 2000: 208).

Do ponto de vista do investimento direto estrangeiro, o Brasil se beneficiou com um fluxo altamente significativo. Graças ao programa econômico de cunho neoliberal, a partir da reformulação da política cambiária (janeiro de 1999), da desvalorização da moeda e da abertura da economia, o país passou a ser um dos principais receptores de IED, recebendo cerca de 30 bilhões de dólares naquele ano, e uma cifra aproximada de 25 bilhões dessa moeda no ano de 2000.

\section{Política exterior e segurança}

Embora o governo Cardoso tenha aderido a "valores hegemônicos universalmente aceitos”, onde o cenário da segurança é identificado como “de multipolaridade com integração cooperativa ou seletiva”24, com a prevalência do livre mercado e de regimes democráticos, a visão dominante no Brasil continua sendo a do realismo (Bernal-Meza,1999), apesar da grande mudança em matéria de segurança, que significou a adesão do país aos regimes internacionais de nãoproliferação, entre eles o Regime de Controle de Tecnologia de Mísseis (1995), a Organização para a Proibição de Armas Nucleares (1996), o Tratado de Proibição 
de Testes Nucleares (1996) e o Tratado de Não Proliferação de Armas Nucleares (1998).

O abandono da opção militar-estratégica de desenvolvimento de armas de destruição massiva (nucleares, químicas e biológicas) criou para o Brasil uma contradição e uma dificuldade. A primeira é que ao impor limites à sua capacidade de desenvolvimento de um componente militar-estratégico, sua aspiração a constituir-se em uma grande potência regional (ou em uma "potência média mundial”) removeu do país um instrumento fundamental nos atributos tradicionais de poder. A segunda é que desenvolver e manter uma capacidade militar-estratégica convencional acreditável ao nível dessa aspiração de "potência” ${ }^{25}$ levaria implícito um grande problema: como enfrentar o custo de criação e manutenção dessa capacidade, sem sustento tecnológico próprio? Pauta-se também a importância que adquire a indefinição em fazer da integração subregional seu efetivo projeto estratégico.

O Brasil define atualmente sua inserção estratégica internacional baseado em dois pilares fundamentais: 1) demarcação da região sul-americana como área de influência (via integração regional), 2) multilateralismo, tanto na área de segurança como na econômico-comercial, que se contrabalança na hegemonia hemisférica norte-americana (Oliveira \& Onuki,2000); dentro de uma política exterior "universalista” que rejeita o alinhamento automático com os Estados Unidos.

Essas duas frentes de ação, as regiões do Prata e Andina, apresentam situações diferentes. A primeira, sobre a base da redefinição das relações com a Argentina - que já identificamos anteriormente - onde se procura atuar via Mercosul, é percebida como uma área de cooperação, apesar dos desencontros com o seu principal sócio, enquanto que a segunda aparece como o foco de maior incerteza do subcontinente, onde são notadas também as diferenças com a política hemisférica de Washington (narcotráfico; Plano Colômbia).

Apesar dos progressos em matéria de segurança nacional entre a Argentina e o Brasil, a partir do "Memorando de Entendimento" (1997), ainda não foi definido o papel da integração econômica regional na configuração da inserção estratégica global do Mercosul ${ }^{26}$. A aproximação da Argentina com os Estados Unidos, tanto em política exterior como em matéria de segurança, impôs certamente empecilhos a essa possibilidade. De acordo com diversos autores, ${ }^{27}$ a percepção norteamericana relativa ao Brasil é que o país mantém uma posição reservada a respeito do estabelecimento de mecanismos institucionalizados de segurança a nível subregional, devido justamente a essa hegemonia do pensamento realista, que o leva a se confrontar com os Estados Unidos.

Em 1996, pela primeira vez na história do país, se estabeleceu uma proposta nacional única de defesa e segurança comuns para todas as forças armadas, criando o Ministério de Defesa. O documento "Política de Defesa Nacional” introduziu a idéia de defesa sustentável na qual continuavam tendo relevância os conceitos 
tradicionais segundo os quais "não se pode abrir mão de elementos como soberania, autodeterminação e identidade nacional. O quadro internacional, visto como cheio de incertezas, torna necessário pensar a defesa como fator importante para que os governos nacionais possam garantir a sobrevivência dos Estados como unidades independentes" 28 .

Esta visão realista da segurança se confirma ao se avaliar a despesa militar, que passou de 1,8\% do PIB em 1985 a 3,2\% em 1998, sendo o mais importante na região ${ }^{29}$. Mas talvez o elemento político-militar de maior importância é determinado pelo fortalecimento da parceria estratégica com a Rússia, declarada por Putin e Cardoso como "associação estratégica a longo prazo"30, para a qual Moscou apoiou a admissão eventual do Brasil como membro permanente do Conselho de Segurança da ONU e ofereceu ao país latino americano a produção conjunta, no Brasil, das séries mais modernas de aviões de combate Sujoi. Trata-se do caça Su-35, um dos aviões de combate mais avançados no mundo.

Esta oferta teve um caráter de extraordinária importância pois, se se concretizasse, permitiria ao Brasil resolver parte do dilema do sustento tecnológico para desenvolver uma capacidade militar-estratégica convencional acreditável, ao nível de uma potência que aspira se estabelecer de forma permanente no Conselho de Segurança. Mas, por outro lado, incorpora um elemento que altera - agora de modo radical - o equilíbrio de forças com o vizinho argentino, fator que é acrescentado à incorporação de porta-aviões, o desenvolvimento de uma nova força de submarinos convencionais e a continuidade do programa de vetores.

\section{Poder e política exterior no contexto histórico}

Tem existido uma constante na política exterior brasileira desde os anos 70, de assumir um perfil ou papel (aspiração, também reconhecimento) de "potência média" ou "potência regional". Associado a este se encontra o de "país intermediário”(Soares de Lima,1986; Sennes,1999). Segundo os autores, ambas as condições têm também atraído o país a uma ativa presença nas instâncias internacionais, questão que ao nosso ver deve ser mediatizada.

Segundo essas categorias de potência, o Brasil dispõe de uma certa margem para definir e procurar suas próprias estratégias internacionais. Os pressupostos realistas implícitos nestas categorias de países os fazem identificar o sistema internacional como hierárquico e oligopolista; eles concebem os regimes e instituições internacionais, principalmente, como reflexo da distribuição estrutural do poder (Ikenberry,1998), ajustando seu comportamento dentro deles através de um cálculo custo-benefício (Soares de Lima,1986;Vigevani,1995). Então, sua participação nos mesmos é fruto de decisões racionais e não idealistas (Sennes,1999).

Como país intermediário, o Brasil, durante os anos 80, manteve seu perfil de política internacional segundo esses padrões. Sua participação nas instâncias 
multilaterais foi uma das características da política exterior. Esse tipo de comportamento aumenta conforme as expectativas que um país tem de desempenhar um papel de realce no contexto mundial (Miyamoto, 2000), na ocasião em que uma melhor exposição internacional e a assunção de compromissos multilaterais favorece a imagem do país como parceiro de negócios internacionais (comércio, investimentos, transferências de tecnologia, etc.).

Porém, as qualidades intrínsecas relacionadas a esses países intermediários sofreriam mudanças drásticas, como conseqüência das profundas transformações ocorridas na economia e na política mundiais. Este fato, no caso do Brasil, levou a mudanças na política exterior: forte adesão aos principais regimes internacionais (o que não significa "ativismo"); uma clara regionalização das principais iniciativas do país e a adoção de estratégias baseadas no reconhecimento da existência de um conflito Norte-Sul. O ponto de ruptura, a partir do qual o Brasil começaria progressivamente a ceder às pressões (e propostas internacionais) dos Estados Unidos, foi a crise da dívida externa, logo que Sarney, sem êxito, tentou criar novas condições de negociação a partir de uma moratória.

Como aconteceu com o GATT, houve uma mudança de estratégia frente ao Conselho de Segurança da ONU, a partir de 1988, que se consolidou em seguida: o aumento substancial de seu involucramento nas discussões, decisões e operações do Conselho. O Brasil aumentava seu compromisso com o Conselho de Segurança na medida que este ganhava importância depois do fim da guerra fria e, como país, reduzia suas manifestações de autonomia (área nuclear, venda de armas, presença no Oriente Médio e na África). Este compromisso maior era coerente com suas aspirações internacionais de país intermediário.

Segundo Guilhon Albuquerque, quanto à dimensão política, as relações internacionais do Brasil poderiam ser definidas como um tipo de participação contraditória: membro pleno de um sistema de segurança coletiva e, por outro lado, ator crítico do sistema de poder nas Nações Unidas; de uma postura rígida de nãointervencionismo, adotando uma política de avaliação, caso por caso, da oportunidade de invocar o direito à auto-determinação ou do dever de ingerência (Guilhon Albuquerque, 2000).

Existem diferentes interpretações para explicar este processo de mudança na política exterior. Em termos bilaterais com os Estados Unidos, muitas das barreiras impostas por este às exportações brasileiras foram sanções da potência hegemônica às políticas brasileiras consideradas ou classificadas como free rider (informática, siderúrgica, produtos farmacêuticos, subsídios). O Brasil fez concessões cada vez que os Estados Unidos aplicaram uma sanção, terminando com a adoção de uma posição de ampla flexibilidade.

Em conclusão, as mudanças ocorridas com o fim da guerra fria aumentaram o custo de se manter fora e ter posições obstrucionistas. A partir de 1996 “o Brasil abandona, discreta e gradativamente, as tradicionais veleidades de combate ao 
atual estado de coisas nas relações internacionais e passa a remar a favor da correnteza. Adeus, conflito Norte-Sul. Nós também queremos ser Primeiro Mundo. A opção da diplomacia de FHC é coerente com sua orientação em política interna. Arquivada a idéia de uma promessa autônoma de desenvolvimento nacional, resta ao país inserir-se, passivamente, na economia globalizada. Aceita-se a posição subordinada como um fato da vida"31. Há uma convergência entre política externa e política interna, um de cujos exemplos é a idéia de que a política exterior representa o programa de governo, algo que é admitido pelos próprios diplomatas ${ }^{32}$. Como no caso argentino, a política exterior brasileira expressa as orientações programáticas do governo. ${ }^{33}$

Ambas as situações, o Brasil como um país mais ativo - "mais visível e atuante no cenário internacional” - e a tendência de liberalização comercial que deixou "vencedores e perdedores", foram reconhecidas pelo ex-chanceler Lampreia como características que identificaram a continuidade e renovação da política exterior de Fernando Henrique Cardoso (Lampreia; 1998). Vários pontos nos quais se sustentava a estratégia brasileira já não existiriam mais, pelos seguintes fatores: 1) mudança no perfil da pauta de exportações e nos interesses internacionais da industrialização brasileira; 2) distanciando dos interesses brasileiros, em vários aspectos, em relação aos tradicionais interesses dos outros países em desenvolvimento; 3) alteração da posição dos Estados Unidos, a partir da rodada de Tóquio, de apoio à multilateralidade e ao uso das cláusulas de favores, passando a exigir reciprocidade, sob a base do princípio de "graduação"; 4) adoção de uma prática comercial voltada para o regionalismo, por parte dos Estados Unidos. Por último, a virtual imobilidade externa do Brasil, dada sua grave crise do endividamento (Sennes;1999).

Não obstante, esse novo perfil do "ativismo" não estava isento de contradições: há uma declaração de vontade de identificar a importância da ONU como fórum de governança internacional, mas a opção pelo multilateralismo demonstra uma inclinação clara e aberta aos fóruns econômicos. "Começa a se consolidar a percepção de que às Nações Unidas caberia prioritariamente o tratamento de questões humanitárias e de segurança. Essa tendência vai de encontro aos princípios que, em 1992, levaram o Brasil a propor uma Agenda para o Desenvolvimento, a fim de que a organização não se dedicasse apenas aos temas da paz, dando então uma resposta imediata às tentativas de enfraquecimento desse fórum de questões prioritárias para os países em desenvolvimento” (Pinheiro, 1999). Para a autora, "não apenas vem se tornando prioritária a intenção do Brasil de reforçar sua atuação na OMC, como também a de fazer parte do G-8”. A realidade é que durante os anos 90, o Brasil se dissociou do terceiromundismo clássico da agenda do mundo em desenvolvimento dos anos 70 , que caracterizou o discurso da política exterior da época.

A hipótese de Cervo para explicar esta mudança é que a ausência de pensamento teórico crítico - ou de pensamento sem teoria - nas relações 
internacionais do Brasil se associou à adoção acrítica do "paradigma da globalização” proveniente do norte (Cervo; 1994; 1999). A influência do primeiro fator impediu que a política exterior brasileira se dotasse de um instrumento teórico que permitisse ao país uma compreensão global do que deveria ser política em um novo contexto mundial. O segundo fator foi uma ideologia que permitiu substituir as políticas nacional-desenvolvimentistas do período anterior e proceder a uma “desnacionalização" ou uma "contra-revolução do desenvolvimento", nas palavras de Cervo. O condutor deste segundo foi Fernando Henrique Cardoso, primeiramente como chanceler de Itamar Franco, e depois como presidente, através da política de desnacionalização. Cervo conclui que durante os anos 90 foi imposta uma filosofia política neoliberal, adotada de forma quase dogmática pelos governos de Collor e Cardoso, baseada em um diagnóstico de distorções ocorridas no modelo anterior de desenvolvimento nacional, como conseqüência das mudanças na ordem internacional, aspecto no qual coincidiriam Menem e De La Rúa (Bernal-Meza, 2000; 2001).

Diversos autores brasileiros (entre eles Cervo e Costa Vaz) coincidem em que, a partir dos anos 90, houve predominância do liberalismo econômico na condução da política exterior, e que a construção de parcerias foi levada a cabo de acordo com essa visão. Segundo Lafer, havia um sentimento predominantemente econômico a ser impresso nas parcerias internacionais (Lafer, 1992: 117). O próprio Tratado de Assunção foi emoldurado no esforço de abertura, já que o mesmo foi apresentado essencialmente como uma continuidade da liberalização comercial da economia brasileira (Nogueira Baptista, 1993).

Nessa perspectiva, as características da integração com a Argentina - e com o Mercosul - passaram a se vincular aos novos objetivos; A parceria estratégica com a União Européia se vincularia com o objetivo de estreitar relações bloco a bloco entre esta e o Mercosul. Mas este objetivo salientava o papel de liderança do Brasil nessa parceria, dando a ela um caráter instrumental para um tema permanente da Agenda: o reconhecimento de sua posição de potência regional. Uma situação semelhante ocorreria, em termos de liderança, com a definição da parceria com a África do Sul, dedicada a uma projeção a nível estratégico no Atlântico Sul, já que o Brasil, além do vínculo bilateral, buscaria desempenhar um papel essencial na construção do relacionamento entre o Mercosul e a África meridional - com os países da SADECC e com o Sul da África.

Iniciativas como as ratificações do Acordo Quatripartite de Salvaguardas Nucleares e do Tratado de Tlatelolco para a proscrição de armas nucleares na América Latina e a adesão ao Regime de Controle de Tecnologia de Mísseis (MTCR) contribuíram de maneira decisiva para a redução das tensões com os Estados Unidos. É mais que possível afirmar que estas medidas foram emolduradas no objetivo de recompor as relações com os Estados Unidos. A Argentina agiria de um modo semelhante. Porém, a elevação das relações bilaterais russo-brasileiras 
ao nível de “associação estratégica de longo prazo”, com os elementos de caráter militar-estratégicos e políticos, analisados anteriormente - e apesar do objetivo de se aprofundar nas relações econômicas e comerciais bilaterais - criará para o Brasil novas frentes de conflitos potenciais, tanto com os Estados Unidos como com a Argentina, tornando importante um forte retorno da vinculação entre poder e política exterior na percepção brasileira do sistema internacional, que historicamente caracterizaram como "hierárquico e oligopolista", com regimes que são o reflexo de uma distribuição estrutural do poder, dentro de cuja pirâmide o país aspira agora, com determinação, escalar.

Em termos de negociações comerciais internacionais - parte da agenda do poder - a ratificação do texto final da Rodada Uruguai do GATT (1994) mostrou uma maior flexibilidade do governo de Franco vis-à-vis o sistema internacional de comércio, que pouco ofereceu ao Brasil, em troca de sua abertura no setor de serviços. Porém, esta política constituiu uma estratégia de inserção e participação na regulamentação do comércio internacional. A integração regional e o Mercosul, além de serem objetivos econômico-comerciais, tornaram-se objetivos considerados sob a ótica estratégico-política. No contexto de um país com aspirações de potência média, esta mudança poderia ser vista como uma resposta defensiva da região (e do país que a impeliu) ao processo de globalização e de normatização internacional.

Entre os policy makers que contribuíram para a construção da base para a "nova política exterior" implementada por Cardoso, merecem ser citados, por suas coincidências (além deste, que foi o iniciador do caminho, quando foi chanceler de Franco): Celso Lafer, Rúbens Ricúpero e Felipe Lampreia; cada um dos quais, em seu momento, justificou a nova política em artigos de ampla difusão acadêmica: Lafer (1996), Ricúpero (1996) e Lampreia (1996; 1997; 1998).

\section{Agenda, objetivos e estilo na política exterior}

\subsection{A evolução da agenda e a definição de objetivos:}

O desenvolvimento econômico:

É o tema que mais tem tido permanência no discurso da política exterior brasileira e sua continuidade é notada na definição das diversas agendas governamentais. Continua sendo o objetivo fundamental, entendido este como “interesse nacional”, através da ampliação do acesso a mercados, tecnologias, investimentos, da cooperação internacional e da melhora na participação do país nos processos de decisão para mudar as regras de funcionamento do sistema internacional, dos seus mecanismos decisórios e dos principais atores. A construção de parcerias estratégicas tem sido fundamental para esse “interesse nacional”, já que é um instrumento para o estabelecimento e formulação de Objetivos. 
A agenda e os objetivos em relação ao Conselho de Segurança e ao GATT:

Em ambos os cenários há uma mudança de estratégia a partir de 1988, e que irá se consolidar logo depois: aumentando substancialmente sua participação nas discussões, decisões e operações do Conselho. Esta mudança está vinculada às novas estratégias na busca de reconhecimento da condição de "potência média" ou potência regional”.

A agenda global passa do "universalismo e multilateralismo" a um "multilateralismo e universalismo seletivo", através da construção de parcerias estratégicas. Durante os anos 90, a adoção da agenda de "valores hegemônicos universalmente aceitos" culminou em uma "reformulação" das opções disponíveis (não proliferação nuclear, abertura à importação de bens e serviços, privatizações, meio ambiente, direitos humanos) e determinou, também, uma participação ativa nos organismos e regimes internacionais. Em relação aos últimos, construir uma agenda positiva e limitar os conflitos (exemplo, com EUA: limitar o contencioso comercial).

\subsection{A evolução dos “objetivos da política exterior” na agenda governamental:}

Sob o governo Collor de Mello, a política exterior teve um duplo propósito: 1) instrumentalizar em âmbito externo o processo de reforma e de abertura econômica, 2) restabelecer a credibilidade externa do país ante seus principais interlocutores no mundo industrializado, rompendo a identificação do país com o mundo subdesenvolvido e imprimindo um perfil renovado e convergente com as teses e postulados de modernidade dos países desenvolvidos. Segundo Azambuja, a política exterior de Collor estava voltada ao aumento da competitividade internacional do país, por meio da abertura econômica e da busca de condições favoráveis de acesso aos mercados, créditos e tecnologias (Azambuja; 1991). Lafer concorda com esta visão, mostrando que havia um sentido predominantemente econômico a ser impresso nas parcerias internacionais (Lafer; 1992:117). Deste modo, dois objetivos aparecem com evidência: atualizar a agenda internacional para ajustá-la às mudanças ocorridas no cenário internacional e construir uma agenda positiva com os Estados Unidos.

Sob o governo Itamar Franco esses objetivos foram condicionados pelos problemas de credibilidade interna e externa (destituição de Collor). Mas um objetivo latente nos anos 70 e 80, retornou com força, através da aspiração à liderança: a busca de reconhecimento internacional como "potência média". Para isso foi construída outra parceria estratégica, como meio para a expansão de oportunidades para seus empresários, e por sua dimensão política, através da criação de uma “Zona de Cooperação do Atlântico Sul”: a reaproximação com a África do Sul.

Objetivos que identificam a agenda de Itamar Franco foram: Reafirmação da não proliferação nuclear; aprofundamento da integração regional e lançamento 
do projeto ALCSA; aproximação a possíveis parceiros (China, Rússia, Índia, África do Sul); ativismo nos foros multilaterais, tentando coordenar a agenda do desenvolvimento com a agenda da paz; e melhorar a relação com os Estados Unidos.

Mas o maior esforço estaria no âmbito dos foros multilaterais: criação da OMC; retorno do Brasil ao Conselho de Segurança da ONU e à América Latina, com a construção do projeto ALCSA (Acordo Sul-Americano de Livre Comércio).

Havia continuidade nos temas da agenda, como a busca de parcerias com outras potências médias; continuidade dos preceitos de "universalismo", amenizar as relações com os E.U.A., tentando distender áreas sensíveis como as já referidas e a propriedade intelectual e as tecnologias sensíveis; mas sua hierarquização e definição foram modificadas por Cardoso, como presidente.

A política exterior continua voltada à realização de objetivos vinculados ao desenvolvimento. O objetivo principal é conseguir do intercâmbio externo elementos úteis à realização dessa meta prioritária, ainda quando este agora se vincule à agenda de valores hegemônicos universalmente aceitos": direitos humanos, políticas públicas (estabilidade econômica, condições favoráveis aos investimentos estrangeiros, aprofundamento do processo de privatizações), meio ambiente e fortalecimento de parcerias.

Porém, não seria fácil reconstruir uma relação positiva com os Estados Unidos e levar o país a uma posição de relevância na visão norte-americana da política mundial. Para distender as relações aceitando negociações sobre propriedade intelectual e tecnologias sensíveis, o Brasil arquivou o projeto de criação de uma Área Sul-Americana de Livre Comércio (ALCSA), que era vista como uma competição com os Estados Unidos e o seu projeto da ALCA.

O Brasil se aproxima dos Estados Unidos; mas as bases da aproximação seriam muito distintas. Deste modo, enquanto para os críticos esta foi a conseqüência da adoção acrítica da "globalização", para os analistas como Soares de Lima "as estreitas relações com os Estados Unidos deixam de ser um meio para aumentar o poder de negociação do Brasil, e se tornam uma conseqüência da sua própria amplificação do poder de negociação" ${ }^{34}$.

As linhas prioritárias de sua política exterior foram as seguintes:

a - Melhoria nas relações com os Estados Unidos. Este objetivo teve uma atenção quase exclusiva.

b - Avançar na integração hemisférica a partir da consolidação do Mercosul, mas arquivando a criação da ALCSA, para não enfrentar os Estados Unidos.

c - Estabelecer uma estratégia de diversificação das parcerias nas relações internacionais do Brasil.

d - Fortalecer a posição multilateralista do Brasil nas esferas econômica e política da ordem internacional. O Brasil ambiciona fortalecer sua presença na OMC e na Rodada do Milênio: seus objetivos mais específicos ali são evitar que as 
posições adotadas em relação aos temas de trabalho, meio ambiente e desenvolvimento, afetem o país; além disso, evitar um retrocesso nas tendências à liberalização do comércio internacional e obter benefícios na questão agrícola.

e - Obter um peso corresponde ao seu poder e importância no processo decisório internacional.

f - Estabelecer relações mais estreitas com a União Européia.

Na questão interna, mas vinculada à gestão internacional, melhoria da diplomacia comercial.

\subsection{Estilo de formulação e aplicação:}

Elementos importantes para identificar o estilo de formulação e aplicação da política exterior surgem das características com as quais se identificam os países intermediários, dos quais o Brasil faz parte. Ao basear-se em pressupostos realistas, estes países ajustam suas ações aos regimes e instituições internacionais através de um cálculo custo-benefício, pelo qual sua participação nos mesmos é fruto de decisões racionais e não idealistas. Segundo alguns autores, as elites governantes e os principais agentes econômicos optaram por uma visão "pragmática” da política exterior, fazendo com que, deste modo, o estilo da política exterior seja pragmático, com um marcado "presidencialismo" (ou diplomacia presidencial), durante o período de Cardoso.

Nesse sentido, o uso da "diplomacia presidencial” (ou de "cúpulas”) uma prática que na política internacional remonta ao Congresso de Viena e que aproximou os líderes da América Latina ao exercício político dos estadistas mundiais - demonstraria ser um instrumento eficaz. Historicamente o Brasil usou a “diplomacia presidêncial” somente nas suas relações bilaterais com seus principais sócios (Argentina, Paraguai, Uruguai e Estados Unidos), fazendo dela um paradigma de diplomacia ${ }^{35}$. Nas relações com a Argentina, por exemplo, existe uma tradição que remonta a 1900, e que teve importantes expoentes (Vargas, Kubitschek, Quadros).

Não obstante, a “diplomacia presidencial” que caracterizou, com variações, as presidências brasileiras desde o retorno à democracia, abarcou diferentes eixos ${ }^{36}$ : instância principal do processo decisório da política exterior e, ao mesmo tempo porta-voz do Estado, muito presente na gestão de Cardoso; diplomacia de iniciativas (mais propositiva), expressa nas presidências de Sarney e Franco; diplomacia de encontros e deslocamentos, onde a agenda de visitas foi a linha mais atraente, que Cardoso também expressou. A construção do Mercosul foi justamente resultado da "diplomacia presidencial”.

Em relação ao continuum passivo/ativo, a política exterior de Collor deve ser identificada como passiva; com Franco esta é mais ativa e reativa, retornando Cardoso a uma política mais pragmática e de menor perfil político. 


\section{Conclusões}

Segundo Cervo (1994), a política exterior apresentou, historicamente, três objetivos que estavam estreitamente relacionados entre si e com uma busca gradual de espaços de ação internacional (maior autonomia): 1) consolidação e expansão do parque industrial, entre 1967 e 1973; 2) desenvolvimento dos setores estratégicos da economia, entre 1974 e 1979; e 3) conquista de tecnologias de ponta e exportação de serviços de engenharia nos anos 80 .

A prioridade sempre foi o desenvolvimento econômico. Os modelos econômicos foram para isso adotados pelos sucessivos governos (substituição de importações, 1950-1985; modelo neoliberal de economia aberta, a partir dos anos 90). Mas o contexto sistêmico mudou e com ele as percepções sobre como moverse neles.

Collor tem uma visão unipolar do mundo, com os Estados Unidos exercendo o papel de potência hegemônica e associando força militar e força econômica. Itamar Franco percebeu que o mundo caminhava para uma "dissociação hegemônica” (Guilhon Albuquerque,1999). Procurou uma aproximação que não excluía a busca de novos parceiros. Esta mesma linha é seguida por Cardoso, ainda quando ele aprofunda a política neoliberal, a qual concebe como o caminho necessário para melhorar a posição internacional do Brasil.

A política implementada por Collor, a partir de 1990 - identificando a agenda e os objetivos da política exterior - teve um pressuposto que a diferenciou das anteriores, e marcaria o rumo das seguintes, que foi a modernização. Porém, ela foi concebida sob a recuperação do liberalismo brasileiro da época de Castello Branco, aggiornado às tendências do neoliberalismo que foram impulsionadas desde Washington. Sua agenda exterior estava marcada por este perfil, incluindo como um dos objetivos a atualização da agenda internacional do país, a construção de uma agenda prioritária e não conflitiva com os Estados Unidos e a redução do perfil "terceiromundista”, tendo em vista as mudanças produzidas no cenário político internacional que, supostamente, levaram a uma atualização das posições mais comprometidas sustentadas pelo Brasil até então, e que eram visualizadas como “polêmicas do poder mundial” (Bernal-Meza; 1999b). Neste sentido, o objetivo era elaborar um discurso cuja interpretação se assentava na idéia de que o fim da guerra fria representava uma fonte de oportunidades e não de aprofundamento do clivage Norte-Sul (Hirst \& Pinheiro; 1995). Como mostraram estas autoras, cada um dos objetivos teve um tema central que se traduziu em uma "agenda específica".

Franco incorporou alguns "novos temas" à agenda, a qual se centrou, essencialmente, no aprofundamento das diretrizes mostradas por Collor. Deste modo, algumas iniciativas indicariam o aparecimento de "novos" objetivos: construção do projeto ALCSA, busca de um assento permanente no Conselho de Segurança da ONU e construção de novas parcerias estratégicas. Mas a sua 
política exterior se caracterizou pelo ativismo, marcando aqui uma ruptura com o estilo anterior. Será sob sua gestão que as divergências políticas com a Argentina começam a surgir com mais evidência, especialmente com respeito às relações com os Estados Unidos e às políticas de segurança.

O período Franco, marcado pelas iniciativas individuais (no caso do projeto ALCSA), foi seguido por uma etapa de dinamismo presidencial, dirigido por Cardoso, mas faltaram iniciativas políticas de grande projeção, desperdiçando momentos de significativa convocação, como a Cúpula de Presidentes (Brasília, agosto de 2000). Alguns analistas ${ }^{37}$ têm atribuído a essa falta de iniciativa os desligamentos que ocorreram no âmbito do Mercosul (4+2), cujo exemplo mais evidente foi a decisão do Chile de negociar um acordo de comércio com os Estados Unidos, mas que também se notou em tendências semelhantes no caso do Uruguai e, de certa forma, na política de double standing da Argentina ${ }^{38}$. Opiniões mais críticas mostram que a diplomacia presidencial de Cardoso buscou resolver retoricamente o vazio criado pela crise do projeto nacional na política exterior (García, 2001). Segundo Saraiva, os objetivos internacionais definidos previamente no governo de Cardoso (governo Collor), que optaram por uma inserção internacional limitada para o Brasil, com a qual se pretendeu substituir o findo modelo nacional-desenvolvista, não foram modificados por FHC. Foi tirado um modelo de inserção internacional sem que fosse substituído por outro (Saraiva, 1998).

Por último, a gestão Cardoso aprofundou a agenda das gestões anteriores, com especial atenção à gestão multilateral, com um marcado ativismo presidencial. O ativismo multilateral se concentrou nos foros econômicos e políticos. Nos primeiros, buscando um fortalecimento da posição do país para facilitar suas exportações, e nos segundos, localizar um perfil de liderança. Porém, é difícil imaginar um ativismo que esteja de acordo com os "valores hegemônicos universalmente aceitos”.

Paradoxalmente, depois da perda de importância da política africana, particularmente distintiva entre meados dos anos 70 e meados dos anos 80 (anos de ativa cooperação mútua e empreendimentos comuns) e o aparecimento da Comunidade dos Países de Língua Portuguêsa em 1996, com que o Brasil buscou retomar seu papel na inserção internacional do continente negro, coincidiu com este grande ciclo de retração das relações comerciais, diplomáticas e estratégicas com os países africanos. As relações do Brasil com a África nos anos 90 foram também um ajuste a um contexto atlântico menos relevante para a reinserção internacional do Brasil (Saraiva, 2001).

Em síntese, a política exterior brasileira foi se adaptando aos novos condicionamentos e cedendo a determinadas pressões que implicaram mudanças em alguns elementos de sua tradição, como é o caso da adscrição ao princípio de "não intervenção" ou a incorporação de temas da agenda internacional que haviam sido rejeitados no passado, como os direitos humanos, meio ambiente, a mudança 
de posição relativa à abertura de novas rodadas de negociação comercial no GATT e a estratégia de reforçar o apoio ao Conselho de Segurança da ONU, abandonando sua tradicional política passiva e opositora, posição que tinha se baseado em uma interpretação crítica a respeito dos processos decisórios da organização.

Os objetivos se diversificaram em relação aos três pólos da economia mundial (Estados Unidos, União Européia e Japão), buscando pôr relevância ao peso do Brasil nos assuntos regionais e internacionais, fazendo desta uma base para o reconhecimento político e institucional (ONU/OMC/UNCTAD) do Brasil como "potência média”. Porém, como mostra Igor Fuser, "arquivada a idéia de um projeto autônomo de desenvolvimento nacional, restava ao país inserir-se passivamente na economia globalizada” (Fuser;1996).

Apesar da maior diversificação - mas sem iniciativas novas - o estilo da política foi marcadamente de caráter passivo, apesar do presidencialismo, na medida que não houve iniciativas, como conseqüência fundamentalmente dos problemas econômicos internos, estruturais e conjunturais, em uma situação de crise econômica, financeira e de infra-estrutura (eletricidade) que se prolongou até o início do novo milênio. A redução das aspirações globais, a persistência de dificuldades com os Estados Unidos e o fracasso de diversas iniciativas econômicas e políticas acentuaram a preocupação do Brasil com um cenário geográfico e político imediato, surgindo a partir daqui uma fase de maiores desencontros políticos e comerciais com a Argentina, que marcariam o fim da década com um momento de incertezas em relação à continuidade do Mercosul e sobre o sentido profundo da suposta aliança estratégica com seu vizinho.

Na relação bilateral argentino-brasileira, foi evidente que os dois países encontraram pontos de divergência cada vez maiores, pois ambos, de perspectivas e estratégias diferentes, buscaram transformar-se no interlocutor natural e privilegiado dos Estados Unidos na América do Sul (a Argentina a partir de sua posição de aliado, o Brasil, de um reconhecimento de sua condição de "potência média”). As coincidências entre Collor e Menem se deram em termos do alinhamento com os Estados Unidos, da percepção sobre as alternativas externas às dificuldades econômicas, da adoção de modelos econômicos neoliberais e das condições estruturais, que nos âmbitos econômico e político, derivaram para ambos os países a partir de suas respectivas localizações periféricas, subordinadas às estruturas da divisão internacional do trabalho e de poder mundiais. Um mesmo objetivo compartilhado de construir na região uma zona de paz e segurança, ambos os países fazendo acordos sobre medidas fundamentais, como a não proliferação de armas nucleares, químicas e bacteriológicas, com medidas de criação de confiança mútua, e a assinatura de acordos (criação da Agência argentino-brasileira de Contabilidade e Controle de Materiais Nucleares, Acordo Tripartite de Salvaguardas com a AIEA, assinatura do Tratado de Tlatelolco), encontrou na agenda norte- 
americana de segurança global (intervencionismo, segurança cooperativa, apoio argentino ao unilateralismo norte-americano contra as posições multilateralistas do Brasil, etc.) o núcleo das divergências, que chegariam ao âmbito do Mercosul, como conseqüência do fato que o Brasil, vendo seu objetivo de "universalismo seletivo" sendo reduzido, retornou às suas maiores preocupações em matéria de comércio subregional.

O novo ponto de inflexão no Cone Sul, que aconteceu com a renúncia de De la Rúa e a chegada ao governo de Eduardo Duhalde, coloca o Mercosul e, em particular, as relações bilaterais argentino-brasileiras, que constituem o seu eixo estratégico, num momento de expectativa. A eliminação da Conversibilidade da moeda argentina e a redução do perfil de prioridade nas relações de Buenos Aires com os Estados Unidos ${ }^{39}$ - que se manifestou no fato de que a primeira viagem ao exterior do chanceler Carlos Ruckauf foi justamente a Brasília - supõem o desaparecimento dos "problemas" que o governo brasileiro permanentemente esboçou como as grandes dificuldades para aprofundar essa aliança estratégica entre ambos países e fazer avançar o processo de integração. A própria situação de crise que vive a Argentina também deveria levá-la a considerar o Mercosul como um ambiente essencial de cooperação solidária. Deste ponto de vista, o Brasil tem uma ótima possibilidade de demonstrar seu compromisso político e econômico com a integração.

O Brasil viveu o período dos anos 90 sob o que Ricúpero (1996) denominaria a "crise de paradigmas". Esta situação, em um contexto de dificuldades econômicas e financeiras internas, deveria projetar ainda por um longo período a resolução de um novo consenso em matéria de política exterior. Desta perspectiva, a adoção de um perfil predominantemente econômico na definição da agenda, fato que caracterizou preferencialmente a política exterior da década, além de justificar-se pela importância e permanência do tema do desenvolvimento na agenda internacional, também se explicaria pelas razões que aqui expomos. O paradoxo do Brasil foi projetar objetivos de "alta política” e privilegiar, como modo de inserção a "perda política" (ou econômica). Existe uma dimensão profunda no perfil econômico que teve o caráter da inserção internacional histórica brasileira. Para especialistas como Almeida (1998), as relações com Argentina, da competição à cooperação e integração, são um capítulo relevante da densa agenda de relações econômicas internacionais do Brasil.

Na minha opinião, existem dois elementos importantes na identificação do estilo da política exterior brasileira. Trata-se de manter aquilo que dá continuidade, regularidade e credibilidade externa à política exterior, evitando o "pendularismo", o "recurso a decisões de impacto”, "as flutuações ideológicas” e o "oportunismo”; mas onde estão os objetivos constantes vinculados com o reconhecimento internacional à sua condição de potência média: participar ativamente do 
ordenamento mundial e se tornar ator central do cenário internacional ${ }^{40}$. O segundo elemento é o resultado do jogo de pragmatismo e flexibilidade, onde o exercício de cada um destes se associa à necessidade de realizar os ajustes necessários para manter a opção dos objetivos. Porém, pragmatismo e flexibilidade são difíceis de se diferenciar quando se aplicam a condutas de racionalidade custo-benefício (por exemplo, flexibilizar a política comercial cedendo às pressões norte-americanas) contra aquelas destinadas a justificar a adoção do que Cervo (1998) e Costa Vaz (1999) concordaram denominando como "uma filosofia política neoliberal, adotada de forma quase dogmática pelos governos de Collor e Cardoso”.

Da literatura sobre política exterior escrita pelos autores brasileiros, se depreende que o Brasil não se caracterizou por uma política exterior de grandes controvérsias internas, com respeito à relação do país com o mundo.

É necessário ir ao fim do século XX, sob o governo de Cardoso, para se notar, pela primeira vez, o surgimento de uma visão profundamente crítica sobre a política exterior. Em parte, o questionamento interno sobre a política exterior foi se aprofundando à medida que a negociação de acordos internacionais, com os Estados Unidos (via ALCA) e com a União Européia (via Mercosul), se transformou em um debate interno de política, entre setores - e lobbies - favoráveis à abertura (importadores) e contrários (os import-competing). De categorias tradicionalmente realistas, alguns autores mostram que o grande problema foi que o debate sistemático e abarcativo sobre o "interesse nacional brasileiro" foi virtualmente esquecido nos últimos anos, porque a sociedade foi absorvida por temas prioritários da agenda doméstica, relegando a segundo plano as questões cruciais da área externa (Magnoli, César \& Yang, 2000:34).

Mas o sintoma mais significativo das profundas diferenças na política exterior de Cardoso se deu no Itamaraty, situação que culminou com a destituição do embaixador Samuel Pinheiro Guimarães de seu cargo de Diretor do Instituto de Pesquisa em Relações Internacionais do Ministério de Relações Exteriores, logo após a difusão de um extenso artigo de sua autoria onde se questionava abertamente a política seguida pela administração Cardoso frente a Alca e aos Estados Unidos ${ }^{41}$.

Esta nova realidade, evidentemente, complica o panorama futuro não somente da política bilateral argentino-brasileira, mas também da política de toda região, já que introduz novos elementos de interferência com o que se supõem as "políticas de Estado, reconhecidas e aceitas”, e agrega novas dúvidas sobre a previsibilidade da política exterior. Tendo presente as eleições presidenciais convocadas para o final de 2002, não deveria esperar-se nada novo na política exterior brasileira até iniciar o ano 2003; no caso de uma nova coalizão governamental, um novo modelo de desenvolvimento levará consigo um projeto de política exterior que substitua o modelo de “inserção limitada”, predominante no período aqui analisado. 


\section{Notas}

1 CERVO, Amado Luiz. Sob o signo neoliberal: as relações internacionais da América Latina. Revista Brasileira de Política Internacional, Brasília: Instituto Brasileiro de Relações Internacionais, Ano 43, $\mathrm{n}^{\circ}$ 2, 2000. p. 5-27.

2 Estado normal significa: "receptivo e submisso aos comandos das estruturas hegemônicas do mundo globalizado"; Ibid., p. 5.

3 OLIVEIRA, Henrique Altemani de. Melhorias na imagem do país e política externa. Carta Internacional, São Paulo: USP-Política Internacional, nº 35, p. 1, janeiro de. 1996.

ROETT, Riordan. The Foreign Policy of President Fernando Henrique Cardoso. Carta Internacional, no 94/95, p. 28, Dezembro 2000/Janeiro2001.

5 Por exemplo, até o presente, o Brasil manteve subsídios federais, estaduais, municipais e financeiros em diversos setores; tem mantido o reembolso de cargas sociais aos exportadores; assegura pré-financiamento ao exportador e ao comprador externo (ACC e ACE), subsidiandoos com taxas menores e mantendo um sistema subsidiado de grãos para os avicultores, suinocultores e criadores de gado. Por sua vez, a Argentina eliminou em 1995 os subsídios à exportação dentro do Mercosul.

Da declaração conjunta russo-brasileira, a conclusão da visita de F.H.Cardoso a Moscou, em 14 de janeiro de 2002.

7 Cuja “Declaração Constitutiva” foi efetuada em Lisboa em 17 de junho de 1996.

8 LIMA, Maria Regina Soares de. Política doméstica determina atuação diplomática. Carta Internacional, $n^{\circ}$ 35, p. 6, janeiro 1996

9 As declarações do presidente F.H. Cardoso sobre isso foram analisadas sinteticamente; ver PFEIFER, Alberto. O Brasil assume a liderança da América do Sul. Carta Internacional, São Paulo, USP-NUPRI, ano VI, No. 63, p. 6., maio de 1998.

10 Apesar de não ser totalmente coincidente, uma destacada literatura se refere a esses aspectos. Ver Bandeira (1996); Barros (1998); Bernal-Meza (1998;1999b); Cervo (1994;1998); De la Balze (1995); Guilhon Albuquerque (1998); Hirst \& Pinheiro (1995); Lege (1995); Altemani de Oliveira, Fuser, Lampreia, Soares de Lima, Genoíno, Cervo, Albuquerque Mourão e Guilhon de Albuquerque in Carta Internacional (1996).

11 Para uma análise comparativa, ver Raúl Bernal-Meza (1999ª).

12 Ver o artigo Argentina-Brasil: Paz y Guerra entre las Naciones, Diario UNO, Mendoza: Séptimo Día. p. 4-5, 4 de agosto de 1997

13 Ver Brasil y Rusia, más cerca, Diario Clarín, Buenos Aires, 15 janeiro de 2002.

14 O embaixador brasileiro Souto Mayor destacou que "cabe reconhecer que não nos temos empenhado em dotar o Mercosul de um arcabouço institucional a altura de nossas aspirações declaradas de fortalecimento do bloco no âmbito internacional, presumivelmente pela dificuldade de conviver como os elementos de supranacionalidade inerentes a tal institucionalização. Em suma, pode-se dizer que há, por parte do Brasil, certa inconsistência entre uma política econômica desnacionalizante (...) e uma política continental de orientação latino-americanista, tendente a criar melhores condições econômicas e diplomáticas de negociação com os Estados Unidos” (ver SOUTO MAYOR, Luiz A. P. Brasil, Argentina, MERCOSUL - A hora da Verdade. Carta Internacional, $n^{\circ} 79$, p. 9, setembro de 1999).

15 Considero um dos mais completos aportes o estudo Sistema Mundial y MERCOSUR. Globalización, Regionalismo y Políticas Exteriores Comparadas (Buenos Aires: Nuevohacer/Grupo Editor Latinoamericano e Universidad Nacional del Centro de la Provincia de Buenos Aires, 2000. 480 págs.).

16 Tal como assinalou Pedro Motta Veiga in MERCOSUL e ALCA: Dilemas para a Agenda Brasileira, Carta Internacional, nº 86, p. 3.,abril de 2000. 
17 Segundo um especialista, “nas negociações da Rodada Uruguai, o Brasil adotou, principalmente nas etapas iniciais do processo, uma posição essencialmente negativa, recusando a ampliação da agenda negociadora e defendendo que as negociações se limitassem à agenda herdada de rodadas anteriores. A posição brasileira foi derrotada por uma coalizão de países desenvolvidos e em desenvolvimento...”; ver: VEIGA, Pedro Da Motta. O Brasil frente à Rodada do Milênio. Carta Internacional, $n^{\circ}$ 76, p. 9, junho de 1999.

18 Intervenção do ministro Lampreia, no seminário O BRASIL E O COMÉRCIO INTERNACIONAL PÓS CINGAPURA, março de 1997, citado por Kjeld Aagaard Jakobsen, O que Esperar da Política Externa Brasileira? Carta Internacional, no 94/95, p. 10-12, Dezembro de 2000/ Janeiro de 2001;

19 Ver RelNet, Resenha Econômica, 237/2001.

20 Predominância do multilateralismo; reconhecimento do clivage Norte-Sul; oposição às hegemonias; apoio “crítico” aos regimes internacionais; autodeterminação e não ingerência nos assuntos internos dos Estados, etc.

21 O Brasil agora faz o inverso do que fazia desde a Guerra Fria. Assim, quando falhava a "carta americana”, o Brasil procurava a “carta européia”. Ocorreu desta forma com a indústria automotiva e com o desenvolvimento da energia nuclear; apoio europeu também em aspectos políticos, ajuda financeira e tecnológica.

22 A mudança no discurso se refletiu de "Não estamos preparados para competir com a economia norte-americana. Com a Alca nossa indústria será completamente desmantelada. Portanto, nos fecharemos, evitando algum acordo comercial com os Estados Unidos”, para "Não estamos preparados para competir com a economia norte-americana. Com a Alca nós teremos que competir mais abertamente. Portanto, nos prepararemos para aumentar nossa competitividade”.

23 De acordo com Flávio de Campos Mello, “ao longo da década de 90, todas as sinalizações dos Estados Unidos no sentido de avançar na integração hemisférica resultaram no fortalecimento do compromisso brasileiro com o aprofundamento e/ou o alargamento da integração sub-regional” (Um Novo Contexto para as Estratégias Regionalistas da Política Externa Brasileira. Carta Internacional, $n^{\circ}$ 96, p. 3-4, fevereiro de 2001). Aqui nós não compartilhamos desse julgamento, a menos que consideremos a "retórica do discurso" no lugar dos fatos concretos. O Brasil não demonstrou na prática uma vontade de se aprofundar no Mercosul, nem em termos institucionais, nem tampouco no sentido da qualidade intrínseca da integração, ou seja, fazendo dele um instrumento não comercial, mas industrial, tecnológico, social e político.

24 Secretaria de Assuntos Estratégicos. Cenários Exploratórios fazem Brasil 2020. Texto para Discussão, Brasília, setembro de 1997.

25 Ou seja, com capacidade de dar respostas militares efetivas aos desafios externos que afetem a consecução dos objetivos e interesses de política internacional.

26 Como mostrou em seu momento Thomas Guedes da Costa; ver: Falta atenção aos temas de segurança internacional. Carta Internacional, $n^{\circ}$ 59, op. cit., p. 13.

27 No caso dos argentinos, em particular aqueles que eram parte da comunidade epistêmica do período menemista. Ver BERNAL-MEZA, Raúl . Las percepciones de la actual política exterior argentina sobre la política exterior do Brasil e as relações Estados UnidosBrasil. 1999, op. cit.

28 MIYAMOTO, Shiguenoli. O Brasil e a segurança regional. Carta internacional, $n^{\circ}$ 89, p. 710, julho de 2000 citando o Documento sobre Política de Defesa Nacional (Brasília, 1996).

29 Fonte: The Military Balance 1999-2000. Londres: Instituto Internacional de Estudos Estratégicos, 1999, citado por Oliveira e Onuki, op. cit.

30 Ver menção $n^{\circ} 11$ precedente.

31 FUSER, Igor. Rumo ao Primeiro Mundo, de pés descalços. Carta Internacional, n 35, p. 2, janeiro de 1996. 
32 Como descreve Maria Regina Soares de Lima, ver: Política doméstica determina atuação diplomática, op. Cit.

33 Uma das expressões coincidentemente críticas sobre o modelo econômico de Cardoso assinala que “ desde 1994 o Brasil adotou um modelo econômico de inspiração externa cujo aspecto principal foi a abertura da economia para o comércio e investimentos, que teve como principais conseqüências sucessivos déficits comerciais, crises financeiras, dois anos de crescimento quase nulo do PIB (1998 e 1999), duplicação da taxa de desemprego, acordos lesivos com Instituições Financeiras Internacionais, enfim, uma abertura diretamente relacionada com o retrocesso econômico e social ocorrido nesta década”. (JAKOBSEN, Kjeld Aagaard. O que esperar da política externa brasileira?. op.cit., p. 10).

34 Citado por J. Castro (1998:94).

35 Embora somente restrita a esses parceiros, tal como assinala DANESE, Sérgio. A Diplomacia Presidencial da Política Externa Brasileira. Carta Internacional, nº 72, , p. 8-9, fevereiro de 1999.

36 Os eixos, a partir da identificação do conceito de diplomacia presidencial ou diplomacia de cúpulas, são citados em DANESE , Sérgio. Diplomacia presidencial: história e crítica. Rio de Janeiro: Topbooks, 1999.

${ }^{37}$ Ver: GARCÍA, Marco Aurélio. O Melancólico fim de Século da Política Externa. Carta Internacional, nº 94/95, Ano IX, p. 6-7, dezembro de 2000/janeiro de 2001.

${ }^{38}$ Ver: BERNAL-MEZA, Raúl. Os dez anos de Mercosul e a crise argentina. Política Externa, Vol. 10, nº 4,; p. 7-46, março-abril-maio 2002.

39 Ainda que esta possibilidade devesse ser relativa, pois além das declarações presidenciais, há dois elementos que agem contra qualquer mudança radical neste relacionamento; um de caráter estrutural, que se relaciona com a dependência político-financeira que Buenos Aires tem do governo norte-americano e de seu apoio às negociações com o FMI em busca de um novo financiamento; outro, de caráter ideológico-político, que tem a ver com a continuidade das alianças (setor financeiro, grandes grupos econômicos monopolistas e partidos políticos) que se caracterizam por suas medidas frente ao novo governo, assim como a visão neoliberal da manipulação da economia.

40 Baseado na crença e convicção de que o Brasil tem um papel de protagonista a desempenhar nos processos decisórios e reguladores das relações internacionais (Mello e Silva,1998; Amorim,1995;1996; Lampreia,1996;1997;1998).

41 Ver: BERNAL-MEZA, Raúl. Os dez anos de Mercosul e a crise argentina. Política Externa, Vol. 10, nº 4,; p. 7-46, março-abril-maio 2002.

\section{Bibliografia}

ABREU, Marcelo de Paiva. O Brasil, o GATT e a OMC. Política Externa, São Paulo: Paz e Terra/ IEA-USP/USP-política Internacional; Vol. 9, nº 4, p. 89-119, março, abril, maio de 2001.

ALMEIDA, Paulo Roberto de. Relações Internacionais e Política Externa do Brasil. PortoAlegre: Editora da Universidade/UFRGS,1998.

OLIVEIRA, Altermani de. Melhorias na imagem do país e política externa. Carta Internacional. São Paulo: USP-Política Internacional, nº 35, p. 1, janeiro de 1996.

AMORIM, Celso. O Brasil e o Conselho de Segurança da ONU. Política Externa. São Paulo, 3 (4), março-abril-maio de 1995.

AZAMBUjA, Marcos Castrioto de. A política externa do Governo Collor. São Paulo: USP, Estudos Avançados, Coleção Documentos, Série Assuntos Internacionais, nº 13. 1991.

BANDEIRA, Luiz Alberto Moniz. Politica y relaciones internacionales en el Mercosur. Revista Ciclos. Buenos Aires: Instituto de Investigaciones de Historia Económica y Social, Faculdade 
de Ciencias Económicas de la Universidad de Buenos Aires, Ano VI, Vol. VI, nº 11, p. 103-122, $2^{\circ}$ sem.1996.

BARROS, Sebastião Do Rego. A execução da política externa brasileira: um balanço dos últimos 4 anos. Revista Brasileira de Política Internacional, Ano 41, nº 2, p. 18-28, 1998.

BERNAL-MEZA, Raúl. Cooperación y Conflicto en la Politica Exterior Latinoamericana: Dos enfoques. Mendoza: Universidad Nacional de Cuyo, Fac. de Cs. Políticas y Sociales/ CERIAL, 1989.

BERNAL-MEZA, Raúl. Las percepciones de la actual política exterior argentina sobre la política exterior del Brasil y las relaciones Estados Unidos-Brasil. Estudos Internacionais. Santiago: Instituto de Estudios Internacionales de la Universidad de Chile, Ano XXXII, nº 125, p. 51-82, janeiro-abril de 1999.

BERNAL-MEZA, Raúl. Políticas exteriores y Mercosur: reacciones ante una crisis. Carta Internacional, $\mathrm{n}^{\circ}$ 79, Ano VII, p. 3, setembro de 1999.

BERNAL-MEZA, Raúl. MERCOSUR: Regionalismo o globalización? Tres aspectos para la decisión de políticas. Realidad Econômica. Buenos Aires: Instituto Argentino para el Desarrollo Económico (IADE), nº 165, p. 32-59, 1º de julho-15 de agosto de 1999.

BERNAL-MEZA, Raúl. Sistema mundial y Mercosur. Globalización, Regionalismo y Políticas Exteriores Comparadas. Buenos Aires: Nuevohacer/Grupo Editor Latinoamericano y Universidad Nacional del Centro de La Provincia de Buenos Aires. 2000.

BERNAL-MEZA, Raúl. Las políticas exteriores de Argentina y Brasil durante los años 90: coincidencias e diferencias. Carta Internacional, nº 88, Ano VIII, p. 7 a 10, junho 2000.

BERNAL-MEZA, Raúl. Políticas exteriores comparadas de Argentina y Brasil hacia el Mercosur. in LIMA, Marcos Costa y MEDEIROS, Marcelo de Almeida (Orgs.). O MERCOSUL no limiar do século XXI. São Paulo: Cortez Editora/CLACSO, 2000, p. 42-52.

BERNAL-MEZA, Raúl. Argentina: crisis coyuntural o estrutural? Carta Internacional, nº 99, Ano IX, p. 7-10, maio de 2001.

BERNAL-MEZA, Raúl. Os dez anos de Mercosul e a crise Argentina. Política Externa, Vol. 10, nº 4, p. 7-46, março-abril-maio 2002.

CAMPOS MELLO, Flavio de. Um Novo Contexto para as Estratégias Regionalistas da Política Externa Brasileira. Carta Internacional, n 96, p. 3-4, fevereiro de 2001.

CASTRO, Jorge. La Argentina, Estados Unidos y Brasil: el triángulo de la década del 90. CISNEROS, Andrés (comp.). Política Exterior Argentina 1989-1999. História de un éxito, Buenos Aires, CARI/Nuevohacer / Grupo Editor Latinoamericano, p. 83-106, 1998.

CERVO, Amado Luiz. Relações Internacionais do Brasil. CERVO, Amado Luiz (org.) O Desafio Internacional. Brasília: Editora Universidade de Brasília. 1994, p. 9-58.

CERVO, Amado Luiz. Os grandes eixos conceituais da política exterior do Brasil. Revista Brasileira de Política Internacional. Brasília: Instituto Brasileiro de Relações Internacionais, Ano 41, Edição Especial 40 anos, p. 66-84, 1998.

CERVO, Amado Luiz. A contra-revolução do desenvolvimento. Carta Internacional, $\mathrm{n}^{\circ} 71$, janeiro, p. 8. 1999.

CERVO, Amado Luiz. Sob o signo neoliberal: as relações internacionais da América Latina. Revista Brasileira de Política Internacional. op. cit, Ano 43, n 2, p. 5-27, 2000.

CERVO, Amado Luiz \& BUENO, Clodoaldo. História da Política Exterior do Brasil. São Paulo: Editora Ática, 1992.

COSTA VAZ, Alcides. Parcerias estratégicas no contexto da política exterior brasileira: implicações para o MERCOSUL. Revista Brasileira de Política Internacional, Ano 42, nº 2, p. 52-80. 1999.

DANESE, Sérgio. Diplomacia presidencial: história e crítica, Rio de Janeiro, Topbooks, 1999.

DANESE, Sérgio. A Diplomacia Presidencial na Política Externa Brasileira. Carta Internacional, $\mathrm{n}^{\mathrm{o}} 72$, p. 8-9, fevereiro de 1999. 
DE LA BALZE, Felipe A.M. Argentina y Brasil: Enfrentando el siglo XXI.in DE LA BALZE, Felipe A.M.(ed.). Argentina Y Brasil: Enfrentando el siglo XXI. Buenos Aires: CARI/ABRA; p. 13-130. 1995.

FUSER, Igor. Rumo ao Primeiro Mundo, de pés descalços. Carta Internacional, nº 35, p. 2. janeiro de 1996.

GARCÍA, Marco Aurélio. O Melancólico Fim de Século da Política Externa.Carta Internacional, $n^{\circ}$ 94/95, Ano IX, p. 6-7, Decembro 2000 / Janeiro 2001.

GUEDES da Costa, Thomas. Falta atenção aos temas de segurança internacional. Carta Internacional, $\mathrm{n}^{\circ}$ 59, op. cit., p. 13.

GUILHON ALBUQUERQUE, José Augusto (Org). Sessenta anos de política externa brasileira 1930-1990. Crescimento, Modernizaçâo e Política Externa. São Paulo: Cultura Editores Associados/USP-NUPRI. 1996.

GUILHON ALBUQUERQUE, José Augusto. A nova geometria do poder mundial nas visões argentino e brasileira. Rio de Janeiro: Seminário IPRI, papel, 1998.

GUILHON ALBUQUERQUE, José Augusto. La nueva geometría del poder mundial en las visiones argentina e brasileña. DE LA BALZE, Felipe (org.).El futuro del MERCOSUR entre la retórica y el realismo. Buenos Aires: CARI. 2000.

GUILHON ALBUQUERQUE, José Augusto. De Novo na encruzilhada: As Relações Internacionais do Brasil às Vésperas do Século 21. Carta Internacional, nº 94/95, Ano IX, p. 13-17, Decembro 2000 / Janeiro 2001.

HIRST, Mónica \& PINHEIRO, Letícia. A Política Externa do Brasil em dois tempos. Revista Brasileira de Política Internacional, Ano 38, nº 1, p. 5-23, 1995.

IKENBERRY, G, John. Globalización, regionalismo y el futuro de la economia mundial. SELA, Dinámica de las relaciones externas de América Latina y el Caribe. Buenos Aires: Corregedor, p. 79-98. 1998.

JAKOBSEN, Kjeld Aagaard. O que esperar da política externa brasileira?. Carta Internacional, $n^{\circ}$ 94/95, p. 10-12, Decembro 2000/Janeiro 2001.

LAFER, Celso. Perspectivas e possibilidades da inserção internacional do Brasil. Política Externa, Vol.1, N³, dezembro1992.

LAFER, Celso. Brasil y el nuevo orden mundial. Arquivos del Presente. Buenos Aires: Fundación Foro del Sul, Ano 1, nº 3, p. 61-80, verão 95/96.

LAMPREIA, Luiz Felipe. Um decálogo para reflexão. Folha de São Paulo, 25 de junho de 1996.

LAMPREIA, Luiz Felipe. A reforma do Conselho de Segurança. Folha de São Paulo, 31 de agosto de 1997.

LAMPREIA, Luiz Felipe. A política exterior do Governo FHC: continuidade e renovação. Revista Brasileira de Política Internacional, Ano 41, nº 2, p. 5-17. 1998.

LEGE, Klaus-Wilhelm. A abertura da economia brasileira e sua influência nas relações exteriores do Brasil. Revista Brasileira de Política Internacional, Ano 38, nº 2, p. 59-98.1995.

MAGNOLI, Demetrio.CÉSAR, Luís Fernando Panelli y YANG, Philip. Em busca do interesse nacional. Política Externa, Vol. 9, nº 1,pp.33-50. junho, julho e agosto de 2000.

MELLO e SILVA, Alexandra de. Idéais e política externa: a atualção brasileira na Liga das Nações e na ONU. Revista Brasileira de Política Internacional, Ano 41, nº 2, p. 139-158, 1998.

MIYAMOTO, Shiguenoli. O Brasil e as negociações multilaterais. Revista Brasileira de Política Internacional, Ano 43, no 1,pp.119-137. 2000.

NOGUEIRA BAPTISTA, Paulo. A Política Externa de Collor: modernizaçâo ou retrocesso?. Política Externa, Vol.1, nº 4. 1993.

OLIVEIRA, Amancio Jorge de, e ONUKI, Janina. Brasil, MERCOSUL e a segurança regional. Revista Brasileira de Política Internacional, Ano 43, nº 2, p. 108-129. 2000.

PINHEIRO, Letícia. A flexibilidade de nossa atual política externa. Carta Internacional, $n^{\circ} 71$, p. 9 , janeiro de 1999. 
RICÚPERO, Rúbens. O Brasil, a América Latina e os E.U.A. desde 1930: 60 anos de uma relação triangular. ALBUQUERQUE, José Augusto Guilhon (org.). Sessenta anos de política externa brasileira 1930-1990. Crescimento, Modernização e Política Externa, op. cit., p. 37-60, 1996.

ROET, Riordan. The Foreign Policy of President Fernando Henrique Cardoso. Carta Internacional, nº 94/95, p. 28, Dezembro 2000/Janeiro2001.

SARAIVA, José Flávio Sombra. Inserção Internacional com objetivos limitados. Carta Internacional, nº 59, Ano VI, p.11, janeiro de 1998.

SARAIVA, José Flávio Sombra (org). Comunidade dos Países de Língua Portuguêsa. Brasília: Instituto Brasileiro de Relaçôes Internacionais. 2001.

SENNES, Ricardo U. Brasil e os Fóruns Multilaterais: o caso do GATT e do CS-ONU (19801995. São o Paulo: Universidade de São Paulo-USP, papel, março de 1999.

SOARES DE LIMA, Maria Regina. The Political Economy of Brazilian Foreign Policy: Nuclear Energy, trade and Itaipu.. Dissertação Ph.D em Vanderbilt University.1986.

SOARES DE LIMA, Maria Regina. Política doméstica determina atuação diplomática. Carta Internacional, $\mathrm{n}^{\circ}$ 35, p. 6, janeiro 1996.

SOUTO MAYOR, Luiz A. P. Brasil, Argentina, MERCOSUL - A hora da Verdade. Carta Internacional, $n^{\circ} 79$, p. 9, setembro de 1999.

VEIGA, Pedro da Motta. O Brasil frente à Rodada do Milênio. Carta Internacional, ${ }^{0}$ 76, p. 9, junho de 1999.

VEIGA, Pedro da Motta. MERCOSUL e ALCA: Dilemas para a Agenda Brasileira. Carta Internacional, $\mathrm{n}^{\circ}$ 86, p. 3, abril de 2000.

VEIGA, Pedro da Motta. O Brasil, o MERCOSUL e a ALCA. Carta Internacional, $n^{\circ} 106$, Ano IX, p. 12-16, Decembro de 2001.

VIGEVANI, Tullo. O contencioso Brasil x Estados Unidos da Informática. Uma Análise sobre formulação da política exterior. São Paulo: Editora Alfa-Omega/Edusp, 1995.

VIGEVANI, Tullo, RODRIGUEZ CORREA, Priscila e CINTRA, Rodrigo. Globalização e Segurança Internacional: a posição do Brasil. DUPAS, Gilberto e VIGEVANI, Tullo (orgs.) O Brasil e as Novas Dimensões da Segurança Internacional. São Paulo, Editora Paz e Terra, p. 53-86., 1999.

\section{Resumo}

O artigo destaca a continuidade na política exterior do Brasil, identificando duas vertentes principais: participar ativamente do ordenamento mundial e tornarse ator central no cenário internacional, tomando como importante referência o Mercosul e a construção de parcerias estratégicas - pautadas sobretudo no desenvolvimento econômico. As relações com a Argentina, da competição à integração, são destacadas na agenda de relações econômicas internacionais. O Brasil, nesse contexto, representa potência regional ante a América Latina e potência média ante o restante do mundo.

\section{Abstract}

The article highlights the continuity of the actions of the Brazilian external policy, identifying two main slopes: to participate actively in the world order and 
become a central actor in the international scenery, taking as important reference Mercosur and the construction of strategic partnerships - based mainly in the economic development. The relations with Argentina, from competition to integration, are outstanding in the agenda of international economic relations. In this context, Brazil represents a regional power in the ambit of Latin America, and a medium power in the ambit of the world.

Palavras-chave: Política Externa Brasileira; Mercosul; ALCA; Integração Regional; Multilateralismo.

Key words: Brazilian Foreign Policy; Mercosur; FTAA; Regional Integration; Multilateralism. 